ARTICLE

Received 16 Nov 2016 | Accepted 20 Apr 2017 | Published 15 Jun 2017

DOl: $10.1057 /$ palcomms.2017.39

\title{
Materializing discourse analysis with James, Schmitt and Latour
}

\author{
Pepijn van Eeden ${ }^{1}$
}

\begin{abstract}
This article describes a turn from a regular discourse analytical perspective to a radical empiricist sensibility and "new materialist" approach, triggered by studying the remarkable wave of political ecology movements in Eastern Europe in the years around the collapse of state socialism. Such a "turn" is not new in itself. Most importantly, it has been pioneered in science and technology studiesin the work of Bruno Latour, Isabelle Stengers, John Law and Donna Haraway. More recently it has been picked up in political theory, by Jane Bennett among others, and is currently gaining momentum with the advent of the Anthropocene, the epoch in which mankind has become the predominant geological determinant, turning the biophysical sciences from a politically "neutral" domain into one that stands today at the heart of political debate. When it comes to the current discourse analysis community, however, taking biophysical actors and materiality into account, as co-shaping political processes, turns out to have its own particular intricacies. In the first part of this study two of the most influential schools in English-language discourse analysis are reviewed in this light - Essex Discourse Theory (DT) and Critical Discourse Analysis (CDA) - focusing on their approach to political ecology and global warming. It appears that CDA, to make strong critique possible, assumes it must project a separate world of intransient 'real' relational structures behind discourse, leading to insensibility over the agency of materiality, animals or physical things, as CDA associates them with this intransient world. DT, on the other hand, relies on Derridean post-structuralism, and refuses to separate a static extra-discursive realm, but tends to regress into narrow linguistic reductionism. In the second part of the study, a three-stepped procedure is proposed for solving these problems, as an expansion of "new materialist" political theory thus far, and an anchor point for further discussion among discourse analysts. It consists of: (1) breaking with the reservations to empiricism, within both the DT and CDA community, by adopting the "radical empiricism" of American pragmatist William James; (2) rooting politicality in materiality by turning to the controversial Carl Schmitt, which reverses critical realist approaches to politicization; (3) drawing material and biophysical objects, humans, and language in the same analytical orbit, without abolishing difference overall, as achieved by Bruno Latour among others. Finally, the third part of this paper shows how the approach that so emerges answers the aporia in CDA and DT, provides a note on its methodic consequences, and emphasizes intersections between current ecological crises, the Anthropocene, and feminist and postcolonial theory, which should further convince that turning to materiality today is rather congruent with the equalitarian and participatory aims of discourse analystsbut also places an urgent call to do away with classic forms of critical realism, and make work of breaking with nature-culture divisionism.
\end{abstract}

\footnotetext{
${ }^{1}$ Centre d'étude de la vie politique, Université libre de Bruxelles, F.R.S.-FNRS, Brussels, Belgium Correspondence: (e-mail: pveeden@ulb.ac.be)
} 
If it is notably difficult to do the anthropology of those who invented the anthropology of 'others', it is in part because they have managed to avoid doing their own. This is why it is fairly useless to try to distinguish philosophy from anthropology when one wishes to find one's way through such an entangled jungle. - Latour, 2013

\section{Introduction}

$\mathrm{n}$ this article, I describe a turn from the regular discourse analytical perspective to a radical empiricist attitude and "new materialist" sensibility. As such, my contribution to this special issue departs from a constructivist orientation, prevailing in discourse analysis today, but works to expand this orientation to all things, including the nature-culture distinction itself, as well as to animals, edibles, bodies, storms, micro-organisms, machines, organizations and institutions, affects and intuitionsin this article all taken together as "things" or "objects". Constructivism therewith gradually adsorbs and transmorphs into realism, but contra the popular critical realism in discourse analysis today.

In recent years, the "turn" toward objectivism and materiality increasingly inspires a rather diverse amount of movements and literatures. ${ }^{1}$ Its overall salience is undoubtedly promoted by our current geological epoch itself, which mainstream scientists have called the Anthropocene, in which a (small part of) mankind has become the predominant geological determinant. ${ }^{2}$ Whether it concerns communication technologies, global warming, artificial intelligence or genetic manipulation, the presumed stability and neutrality of "products of nature" is rapidly disintegrating, leading biophysical and material objects to take up roles at the heart of contemporary political debate. From a more daily point of view, meanwhile, we increasingly construct our identities online, independent from the objects around us-but precisely by doing so, our dependence on complex compositions of plastics, aluminium, glass-fiber, cobalt or titanium becomes ever more evident - or in in the words of Nick Vaughan-Williams and Tom Lundborg recently, it is "not only that human beings are surrounded by, immersed in, and indeed composed of matter, but also that the relationship between people, materiality, and socio-political life is intensifying" (2015: 1). In view of technological developments and ecological upheaval, objects and things are bound to become ever more pressing in the policies and politics of the years to come, and enlarging the current domain of political analysis, for taking them into account properly, is of particular urgency. From the current discourse analytical perspective, however, there are particular intricacies and barriers in place for doing so.

The attempt to explicate these intricacies and barriers, in the current article, arose from an ongoing research project to the remarkable wave of politicization of ecological issues in communist Central and Eastern Europe toward 1989, and their subsequent depoliticization in the 1990s. From the 1960s onwards, similar to Western Europe and the United States, a growing number of state agencies, writers, civilians, groups, and other networks in state socialist Europe started to articulate great worry on a range of ecological problems, from water pollution to industrial waste problems. In the 1980s Marxist-Leninist discourse had become hollow and its modernizing pathos farcical-even for the much of the establishment. At this point ecological issues evolved into strategic gathering points for oppositional forces. Not only did they offer safe because assumedly politically neutral niches for opposition, the claim to scientific objectivity was also one of the core pillars of state socialism, and could now be questioned by pointing to the pertinence of real ecological issues. After glasnost was announced, and Chernobyl had happened, "ecology" rose to the top of the political agenda all over the region. Eco-political agendas were pushed by anti-communist activists, scientific networks, reformist party factions, official scouting clubs, state conservation agencies, church networks and anarchist initiatives-and although nowadays largely forgotten, ecological controversy strikingly often played a key role during the revolutions of 1989, most obviously in Hungary (Danube waterworks controversy), Estonia (phosphate mines controversy) and Bulgaria (Ruse air pollution controversy).

After the regime change of 1989 most of the leading members and advocates of these groups "flew out", often filling high ranked offices within government administrations, consultancy bureaus, academia, or business elites. The eco-political themes of the late 1980s gradually moved to the background. Ecological political parties were founded with great anticipation but were almost entirely unsuccessful. There was a boom of environmental NGOs, certainly in the first half of the 1990s, but under "transition" and "Europeanization" these developed as technical policy advice organizations with little ability to mobilize politically-some have spoken of "NGOization of collective mobilization" during this epoch (mostly from a feminist perspective, cf. Jacobsson and Saxonberg, 2013; following Lang, 1997). Others, less diplomatically, of "chasing the green buck" (Agarin and Grīvinuš, 2016).

To this backdrop my research has been preoccupied with the question of politicization and de-politicization of ecology-or, as Marc Elie and Laurent Coumel put it, with ecologization and deecologization (Marc Elie, personal communication, 15 May 2016). Owing to its setting in Central and Eastern Europe in severe crisis, the project demanded an alternative for Western-centrist perspectives, according to which eco-politicization has generally been attributed to increased "environmental risk" formative of "reflexive modernization" (Beck, Giddens) or, ever more problematic, as socio-economically determined: a political side-product of the affluence "late-capitalism" propelling the arrival of "postmaterial values" (Inglehart). In the search for an alternative, an interpretivist, social constructivist, discursivist line of approach was taken up as a matter of course-but this soon proved to produce its own problems: the studied processes induced roles for objects in the analysis which could not be grasped with the existing discourse analytical terminology, methods, or approaches. Yes, discursive processes were of crucial importance, but had actual ecological issues-the radioactive particles in the Dnepr, the chemical clouds thriving over Bulgarian Ruse, the threatened drinking water aquifers linked to the Hungarian Danube-not also played themselves some role in their own politicization?

In this article I am trying to overcome this insensibility for objects, especially biophysical ones, emerging from today's discourse analytical spectrum. In the first section, I aim to find out on the character of the barriers at play. For doing so, I rely on the open ethnographic orientation as employed in sociological science and technology studies (STS) for studying scientific communities-which is suited perfectly for the sort of jargon-free but in-depth interdisciplinary discussion this journal is aiming for. Thus, I will not embark on a systematic discourse analysis directly, but rather draw an "empirical ontology", as John Law called it, of the discourse analytical community. With a small excerpt from an interview with the great political discourse theorist Chantal Mouffe, I start off with a major challenge for the radical constructivist position of the Essex school of Discourse Theory (DT), over strategic positioning in embattling climate scepticism. From this point onward, I investigate the ontological controversies over the "extra-discursive" or "non-discursive" in discourse analysis at large, between Essex DT, on the one hand, 
and Critical Discourse Analysis (CDA) on the other, concentrating on its Faircloughian current. The empirical data consists of field observation, secondary observational notes, and the written literatures, discourses, and behavioural patterns of the discourse analytical community itself.

It so appears, of course, that DT is post-structuralist inspired, generally following Derrida's famous il n'y a pas de hors-texte: all things are "always already" constituted as text, as a texture, interwoven already before being written or talked about. Although this provides fertile theoretical ground for awarding political agency to materiality, animals and plants, or things and objects, in actual practice Derrida's motto regresses all too often into a narrow linguistic reductionism, in which there is paradoxically hardly any attention for, let's say, the "flesh and blood" of actual life-let alone for the interference of a goldfish, for example. CDA, on the other hand, dismisses post-structuralist DT under the argument that it fails to explain social stability. Closer inspection then demonstrates how in CDA the Bhaskarian critical realist worldview, which propagates the separation of discourse from a realm of structural relations, is of archetypical standing. This at first appears to be more common-sense and more appreciative of climatology, actual materiality, fabrics, animals, or things, which it considers as part of the "objective" structural realm. However, it then turns out that this structural realm is conceived as intransitive, transcendental, and invisible-thus blocking any sensibility toward biophysical and material actors ever more effectively, and hence failing to acknowledge them as co-shaping political processes, let alone as pro-active mobilizing forces.

The second part, then, moves away from this "empirical ontological" exploration of current discourse analytical perspectives toward a series of concrete proposals for improving the situation, and "materialize" discourse analysis. It can be noted here, in this introduction, that approaching the discursive and political sphere from a "materialist" angle bows on a number of illustrious predecessors. Useful anchors can be found in Anaximander of Miletus, Aristotle's Tyche (chance, as opposed to automaton) in his Physics rather than Metaphysics, or in Machiavelli's disruption of political idealism by actual experience. More contemporaneously, Marx' attempt to come to a historical materialism has undoubtedly been the most influential, although with mixed results. Among discourse analysts, Lacan's "Real" is well known, with which he managed to smuggle the material world into psychoanalysis. Then, Althusser took Marx and Lacan together in his "materialism of the encounter" or "aleatory materialism", which may be pointed to as an immediate precursor of the "new materialism" professed here. ${ }^{3}$ For the current discourse analytical community, they remain important potential entry points, and forgetting their inspiration seems altogether unwise (cf. Vaughan-Williams and Lundborg, 2015). That said, in expanding the critique on both linguistic reductionism and critical realism in discourse analysis today, I move away from the above usual suspects, and aim instead to associate new and perhaps surprising figures with the turn to materiality in political analysis (that is, as so far developed by Benett, 2009; Braun and Whatmore, 2010; Coole and Frost, 2010; Vaughan-Williams and Lundborg, 2015).

It is important to note that, in this second section, I am not elaborating any method, let alone a theory, which is yet another limitation of this contribution, and a possible alleyway for further research-as outlined in the third section of this article (paragraph Answering questions on method). With more honour for the titled intellectuals than myself, I merely outline a threestepped procedure with which discourse analysts could attempt to break through the division of the world between a political discursive-linguistic realm and a neutral one of objects, with which the problems sketched out in the first part can be overcome, in terms of broad analytical approach. The first step: turning toward the pragmatism and "radical empiricism" of William James. James frees the empiricist tradition from its association with "the doctrine of mental atoms", as he calls it, to instead include all things experienced. For analysts of discourse, adopting this stance means a fundamental departure from the anti-empiricism of both DT and CDA, but turns out not at all at odds with DTs differential ontology, its agonistics, radical pluralism, and its emphasis on contingency and historicity. It does however open up the space to take actual objects into account-through perceptual experience-while remaining attentive to internally coherent systematizing as always inadequate but crucial: pragmatically emphasizing the importance of perspectives, structuration, organization, models, measurements, and even metaphysical theorizing for orienting ourselves. Claiming the empiricist tradition while doing so, moreover, is potentially of explosive strategic value in the battle for hegemony in contemporary social and political science.

The second step consists of reconfiguring what discourse analysts tend to take as the distinctive characteristic of the discursive realm: the political, politics, and politicization. In addressing this point, I amend a scheme on politicization by Colin Hay-another prominent follower of Bhaskarian critical realism (Hay, 2007; Figs. 1 and 2). In typical critical realist manner, Hay describes politicization as a process that starts when a given issue moves out of what he calls a "realm of necessity", after which it enters private debates and then public discourse, finally ending up in the "governmental sphere" when fully politicized. Informed by James' radical empiricism and the controversial work of Carl Schmitt, I show how Hay's scheme easily leads to narrow positivist misunderstandings. In 1988, the atmosphere in the Bulgarian town of Ruse did not politicize simply because it entered the domain of the established political class. Rather the opposite: it politicized when a new element presented itself-chlorine-which could not be integrated,

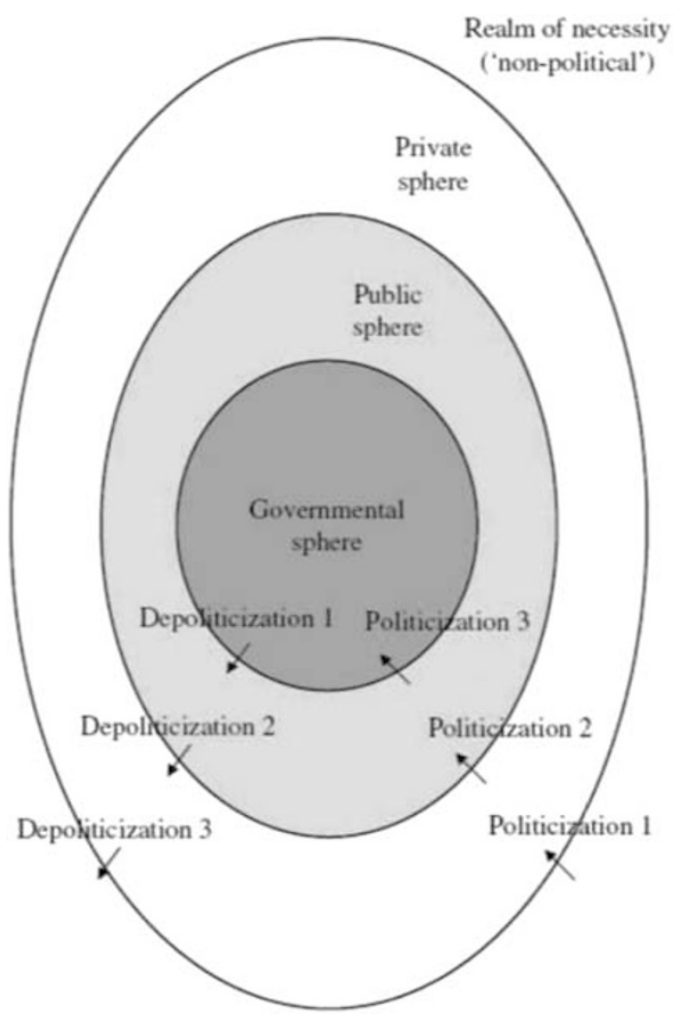

Figure 1 | Politicization according to Hay. 


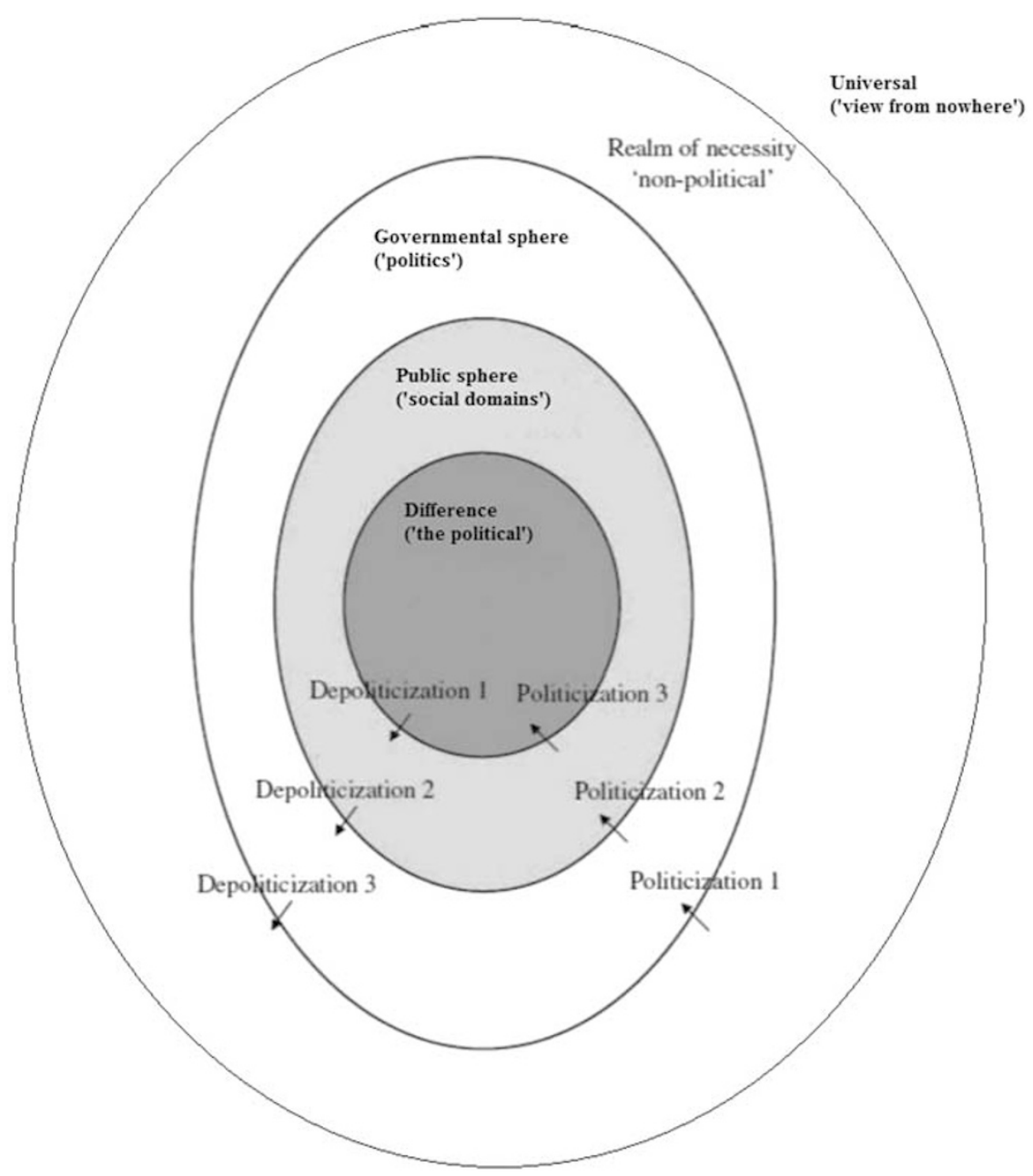

Figure 2 | Hay's scheme amended with James and Schmitt.

neutralized or pacified by the established system in place. The movement Hay describes must be reversed along these lines: at least to the degree that the "governmental sphere" fulfils its duties properly, it institutionalises, orders, categorizes, bureaucratizes, codifies, pacifies, and neutralizes political controversies-its essential function is to de-politicize. If it turns out to be incapable of doing so, regime-change might well be in the air, as was the case in Bulgaria. In a third and last step, I then lay out what could be called a "new materialist" approach to political discourse and its analysis, which effectively consists in extending constructivist sensibilities to real objects. I concentrate on what had all along been the main source of inspiration for this article: the work done in STS and material semiotics by Bruno Latour, Antoine Hennion, Isabelle Stengers, Donna Haraway, Isabelle Stengers, John Law, Donna Haraway and many others. I discuss the commonalities this sphere still shares with DT, especially, as well as the potential of renewed intercourse with the discourse analytical community, due to the latter's often more straightforward political sensitivity and explicit engagement with equalitarian and participatory aims.

After this three-stepped procedure, the discourse analyst might have been sensitized for breaking through the boundaries of DT and CDA, and take the agency of animals, plants, storms or fabrics into account. In the final and third section, then, I try to consolidate this possible achievement, by discussing how it enables particularly strong resolves on the remaining controversies of the first section: formulating a decent strategy toward climate scepticism, and explaining social stability. I include a short note on the consequences for existing discourse analytical methods, and lastly I draw how, in view of the catastrophically inevitable, this academic discussion on turning to "radical empiricism", "materialism" and "biophysical objects" must lose its naïveté-as it is forced upon us by the Earth's ecological ruptures. For those discourse analysts willing to adopt the materialist point of view and its exciting but also frenzied, sinister, frightening outlook today, the very last paragraphs deal with Marxian dismissal of the term "Anthropocene", under the argument that it generalizes the whole of mankind as equally responsible for the ecological crises, rather than pointing out that a tiny group of Western upper-class white men bear most of the responsibility. Although there is much truth in this, from the Central and Eastern European experiences with state-socialist modernity, it is quite clear that alternatives like "Capitolocene" (Moore, 2014) or "Anglocene" (Baviskar, 2015) are not entirely satisfactory either. ${ }^{4}$ It is instructive in this regard not to let the proposed starting date of the Anthropocene, August 1945, obfuscate the historical enormity of our Anthropocenian shock. Rather, and again with the help of Haraway, Latour, and Stengers, and anticipated by feminist and postcolonial scholarship, it is important to remark that it signals the end of Plato's age-old template in which material and biophysical agencies have no place, due to a division of the world in intransitive, transcendental (objective) ideal-real Forms on the one hand and their shadowy everyday (discursive/political) reflections on the other. The break 
with this divisionism, today called for by the Earth itself, is bound to end contemporary capitalism as we know it-even if it problematizes established discourse analytical practice as well.

\section{PART 1 controversies}

Controversy on climate: The reference of Chantal Mouffe. Some time ago I had the honour to interview Chantal Mouffe, for a magazine outside of academia, mostly as the result of her role in the wave of leftist populism that rolled over Spain and Greece (Van Eeden, 2015). I could not resist asking her a question that had sprang from my own research. If "everything" depended on perspective and interpretation, as seemed to be the position she upheld as co-founder of the Essex school of DT, then there are apparently no absolute boundaries or laws or even ecological disasters outside of the discursively constructed-but what then to do with climatology and the urgent problem of global warming? The following presents a fragment from the transcript:

CM: Nature is a discursive construction.

PvE: Exactly, so this is where many environmentalists would disagree because they conceive nature, you know, in the tradition of Malthus, the Club of Rome, Limits to Growth: as something that imposes certain absolute limits. If we do not take care of it the world, we humans as well as life on Earth will be destroyed. This suggests nature is something quite different than a discursive construction.

CM: That nature is a discursive construction does not mean that there is not something out there which is eh... But when we speak about it, then no: if we speak about it, then nature is not outside of discourse. I mean the separation between the two: here I would definitely follow what Bruno Latour said, you know. Do you know his work? [...]

PvE: But doesn't a 'soft approach' leave the door open for climate scepticism and the populist right, who are successfully taking over the debate, certainly in the US.

CM: Yeah, yeah, yah.

PvE: But this is then a problem.

CM: But this is exactly why I think that, basically, one should not base ecological politics on science. I'm not saying that it should not be part of the argument-but I mean, the main commitment to ecology should not be based on science. (Mouffe, personal interview, 8 March, Brussels, 2015)

The dilemma here is strategic: most "green" political discourses are greatly reliant on science for providing an authoritative vision on absolute limits outside of any political construction, overstepping which would lead to apocalyptic disaster. On the bookshelves of virtually every environmental organization, although perhaps a bit dusty nowadays, stands a copy of Limits to Growth. This extremely influential report from 1972 was a product of early World System Science, which, on the basis of a number of graphs and tables, concluded that:

Given the finite and diminishing stock of non-renewable resources and the finite space of our globe, the principle must be generally accepted that growing numbers of people will eventually imply a lower standard of living. [...] We are unanimously convinced that rapid, radical redressment of the present unbalanced and dangerously deteriorating world situation is the primary task facing humanity. (Meadows et al., 1972)

Those adopting radical constructivist position, however, appear to undermine such a conclusion, by drawing attention to its socially constructed character. Consequently, when global warming is on the table, even radical progressives, which under most circumstances are decent social constructivists à la Mouffe, tend to swap their position for an a priori defence of the authority of Science instead-typically arguing that if we do not unconditionally start respecting and listening to the Laws of Nature, our civilizations are on the eve of destruction. Consider Greenpeace, only recently:

Today, the world's leading authority on the science of climate change released a report that shows the concerns of the Greenpeace activists are completely justified. (Tunmore, 2013, for Greenpeace International)

That's why we've set up the Laws of Nature campaign. Together we're going to stop the people trying to use Brexit to trash nature. (Greenpeace UK, 2016)

Mouffe however, as a prominent constructivist political thinker, a former student of Althusser, and inspired by Derrida and Foucault, remains of the opinion that "everything", including science, is socially constructed, subjected to struggles for power and political hegemony. Even if written with capitals, the Laws of Nature are discursive, and thus intertwined with political agonistics and power struggles. One of her political allies, Eric Swyngedouw, works tirelessly to point out the problematic politicality of much environmental discourse in this regard: "the discursive matrix through which the contemporary meaning of the environmental condition is woven, is one quilted by the invocation of fear and danger" (Swyngedouw, 2014). To have a consistent argument, would Mouffe, and with her progressive constructivists in general, not have to agree, at least in principle, with those Trumpist US climate sceptics that draw climatological insight as a fear-mongering and repressive political discourse, a socio-political construction, subject to competition for power and hegemony, threatening our freedom? Or to put it even more provocatively: would constructivists not have to allow Trump's infamous framing of global warming as a hoax of the Chinese as "one of the possible interpretations"? If so would social constructivism then not contribute to the disqualification of objective climatology, and endanger life on Earth by so doing? Indeed, was it not the constructivist movement that first pioneered the "post-fact" reality that we live in today?

Chantal Mouffe, for one, while answering all my other questions with immediate and abashing replies, conceded that, while upholding a radical constructivism, the strategic problem of climatology was a rather interesting one, but one that she had not yet studied that profoundly. She would be interested in it though, but referred me to the work of Bruno Latour for an answer.

Controversy among discourse analysts: DT versus CDA. We will come back to Latour later. First, for further clearance of what is at stake here, we will have to discuss a wider controversy within the discourse analytical community, between on the one hand DT in the tradition of Mouffe and Laclau, and on the other CDA. This because, from the perspective of discourse analysis at large, CDA seems to offer a straightforward, common-sense alternative to the DT approach, for coming to terms with "hard" material or biophysical objects and scientific objectivity. To see if the solutions provided by CDA are tenable, we need to move our investigation to the ontological level. To quote the renowned ethnographer of science John Law: we need to engage in "empirical ontology"; that is, to investigate the CDA and DT communities in their "answer to the question: what is the nature of the [social and political] reality to be investigated?" (cit. Blaikie, 2007: 6, brackets added; Law and Lien, 2012: 12). ${ }^{5}$ 
Before starting with such a daring enterprise a preliminary note on complexity is in place: researchers drawn to one of the two schools quote, borrow, switch sides, collaborate and discuss extensively with those tending towards the other. ${ }^{6}$ As always, any clear-cut dichotomy is an aberration when looking at actual practice. Even more problematic is that CDA and DT each fall apart in many different sub-camps. In DT there are notable differences between those adopting a more Foucaultian, Mouffean, Laclauian, Žižekian, Lacanian, or Althusserian approach. Especially the latter two, perhaps latter three, arguably offer some more room for turning to materiality and the objective, with abovementioned concepts as "materialism of the encounter" or "the Real".

CDA is even more diversified; under its header, there are multiple formalized currents with very different theoretical leanings, offering different methods: Teun van Dijk's Sociocognitive Approach, Siegfried Jäger's DA, Ruth Wodak's Discourse Historical Approach, the Corpus Linguistic Approach of Gerlinde Mautner, the Dialectical-Relational Approach (DRA) of Norman Fairclough, and the Social Actors Approach of Theo van Leeuwen. Below I will concentrate on the Faircloughian tendency, which thus in no way represents the entire CDA community. Nevertheless there are important shared elements within CDA, which should already be clear from this obsession with capitalized "Approaches" itself. This is generally condemned in DT as, in the words of figurehead David Howarth, a "balkanization and reification of methodology. (2005: 317). Howarth has perhaps been overly rude-it might be more polite and productive to take up Law's empirical ontology, in an attempt to understand the reality of CDA communities, as apparently including an urge to provide for (or, in the lower echelons: be provided with) one or the other pre-determined "Approach" by which discourses can be analysed. As we will see, the worldview explicitly adhered to by the Faircloughian tendency renders this urge well understandable and according to some pragmatic instructions, then, it follows that it is plausible that its worldview is to a degree shared all over the CDA spectrum (Peirce, 1934, Chapter 7).

Approaching the object with DT. Let us first inspect DT's worldview more closely-away from Mouffe's personal theorizing, into the communities of actual practitioners. DT analysts are typically claiming a post-Marxist and post-foundationalist stance, inspired by what has been called post-structuralism. They name the impossibility of a firm ground, structure, or stable identity as the very starting point of their analysis. Everything in the world is ultimately moving and contingent. When it comes to foundations, community leaders like Mouffe, Laclau, Stavrakakis, Howarth and Norval vary on Derrida's deconstruction and rhetoric of undecidability, for example, and understand truth radically in the plural, always indefinite, always postponed and dependent on perspective and interpretation, and therefore simultaneously at stake as well as the outcome of political struggle. Indeed, agonistic radicalism and the redefinition of Gramscian political hegemony, as developed by Mouffe and Laclau, and crucial in all of DT, are inconceivable without this non- or post-foundational ontology.

According to DT practitioners, then, our political preferences, our character and choices, our unconsciousness, as well as our scientific insight, are structured relationally like language, fluctuating and floating, changing intersubjectively. This community traces its intellectual roots, its commitment to equality, and actual political allegiances, to the socialist tradition, but then associates with the triad Nietzsche-Heidegger-Derrida rather than with Marx, claiming that transcendental constancy is an illusion to be eliminated in favour of radical historicity. Consequently it urges to break with static Marxist concepts-its historical materialism, fixed categories, economistic stagism, and "social structures"-for replacing them by discursive "nodal points", that are always open for new interpretations and articulations. Those adopting this line of approach even consider mathematical axioms a contingent "nodal point", a "sedimentation", and therefore inextricably intertwined with political power. Consequently, to come to enlightenment and emancipation, DT practitioners tend to dedicate themselves to the Heideggerian task of finding new concepts and terms, providing dissenting interpretations, promoting alternate narratives, construing, constructing and promoting discursive "chains of equivalence" for winning political hegemony, all under the assumption that our ideational categories and discourses are not simply an aspect or consequence of "social reality" but actively constitute it.

From this perspective, then, we should be decided in acknowledging that scientific ecology is a discursive construction and hence "always already" political. With regards to "green ideology" Stavrakakis showed how it emerged as the result of two discursive "dislocations": the first as the shock among the radical left in Europe aroused by the failure of May 1968, and the second as the shock of "the environmental crisis" at the start of the 1970s. Afterward, what was coined as green ideology surfaced as a shared discursive nodal point for a wide range of political groups in Western Europe that defined themselves against "the establishment", often enchanted by May "68, but unable to find any common ground internally before the environmental crisis came along and provided a common rallying point (Stavrakakis, 2000). This assessment certainly provides important openings to better understand the emergence of political ecology more generally. It acknowledges that ecological "dislocation" or catastrophe, in its immediate experience, is ideologically radically underdetermined. Therefore this approach can also be applied outside of Western Europe: in Africa, South America, for example-or in Central and Eastern Europe during state socialist times. In Central and Eastern Europe, when "environmental dislocation" first struck, and especially after Chernobyl in April 1986, network groups outside of the establishment, progressive in the broad sense of the term, but certainly not always on the left, indeed often developing nationalist, liberal or otherwise anti-communist perspectives later on, gradually monopolized the ecological banner (cf. Van Eeden, 2017).

But as mentioned, it is still hard to really appreciate the agency of clouds, radioactive particles, or aquifers from this perspective. Where can we locate this biophysical dimension, the event of this "environmental dislocation" exactly? Mouffe's silence speaks volumes: "this does not mean that there is not something out there which is eh ..." Nothing can really be said about "it", as that would mean it already appears in discourse (cf. in this regard Lacan's conception of the Real, Derrida's negative theology, Wittgenstein's later work). One could rightly argue that, when embracing radical contingency and a differential ontology, dislocations do not need to be accounted for any longer: intertextual chains in the symbolic realm of language are always incomplete, and change and difference take ontological primacy. But should we really hold on to our (simplified!) readings of Derrida in this case, and reduce everything to language because "there is no outside-text"?7 A quote from the work of Maarten Hajer, one of the most acclaimed and ground-breaking in employing DT to analyse environmental policy discourse, illustrates this problem. Hajer's work aims to unravel "discourse coalitions" in environmental policy making. From his research to the problem of acid rain: "through the controversy of acid rain, actors were actually fighting a much more complex political battle" (Hajer, 2005: 310). Although he is certainly correct overall, 
the sentence still rolls over the influence of rain itself, or rather over the set of acid chemicals that appeared in it, on its own politicization. The three-stepped procedure outlined in the second section of this article advances an analysis that agrees with Hajer's analysis overall, but has "through" replaced by "with", and deletes "actually" and "much more": "with the controversy of acid rain, actors were fighting a complex political battle". Or perhaps even "acid rain drew many other actors into a complex political battle". As we have already seen, evading the "hard" physical core of the question, as DT tends to do, and as Hajer exemplifies, becomes ever more problematic, philosophically and in eco-political strategy, when global warming, climate change and climate scepticism are on the table.

The opposition of CDA. At least until the Laclau-inspired Podemos rose to prominence in Spain, the most often heard critiques from CDA communities (and many others) on DT focussed on its alleged "otherworldliness"-its intellectualist "ivory tower"-or even its "difficulty". Still today, the CDA community typically defines itself as more "practical", and more directly informed by on-the-ground struggles against racist, sexist, or socio-economic inequalities. However, after closer investigation, CDA practitioners also find common-ground in answering Blaikie's ontological question in a different way than the DT community.

Of all currents in CDA, the Faircloughian strand is perhaps the most articulate in its opposition to DT. Fairclough, and the DRA he co-designed, inspires on the British critical realism of Bhaskar and Gorski, which explicitly calls for the assumption of an intransient, transcendental relational structure as constituting the reality behind everyday appearances (for an introduction: Sayer, 2000; Bhaskar, 2008; Gorski, 2013). The political scientist Colin Hay, who is not directly connected to CDA, but a prominent critical realist, perhaps best explicates how the traditional critical gesture-the $\mathrm{C}$ of $\mathrm{CDA}$-implies this ontological division between a "real" intransient transcendental structure, on the one hand, and everyday discursive practices, on the other. According to Hay, a proper critic has to accept that the world "does not present itself as it really is".

If we are to reveal the structured reality of the world we inhabit, we must cast our gaze beyond the superficial realm of appearances, deploying theory as a sensitizing device to reveal the structured reality beneath the surface. It is this "depth ontology" which underpins critical realism. (Hay, 2002)

In other words, a critic has to assume an invisible but more real reality consisting a structured body of relational mechanisms and principles "out there", beyond the appearances of "the surface". Only with such a "depth ontology" can a critical realist legitimize her project, which is to make visible these structures through critique, to come to enlightenment and emancipation.

One of the most emblematic and influential transcendental structures employed in this way is, of course, the Marxian relational-economic one, for which the most vehement preservational work in CDA is done by Fairclough's DRA, not in the least by Fairclough himself (for example, 2003). In an inspiring precursor to this ethnographic exploration of discourse analytical communities, Egan-Sjölander (2011) confirms that such a strong transcendental structuralism is probably the most important, most fundamental issue that differentiates CDA adherents from DT adherents overall, based on observations made in 2008 in Sweden at a roundtable of CDA and DT practitioners. But then, is the circular utilitarian argument of Hay the only one for answering the theoretical steamroll of DT-that is, to the challenge posed by assuming radical contingency rather than an intransient structure? In CDA, Chouliaraki and Fairclough (1999) have perhaps delivered a more thorough answer in this regard. Building on earlier critiques on DT in a Third Way neoGiddensian fashion (from Nicos Mouzelis, 1990: 20-38), they argue for preserving traditional structuralism as the only way to explain empirical stability in human interactions. According to Chouliaraki and Fairclough:

the basic problem with this [replacement of a priori structures with discursive nodal points] is that it is unable to explain which social forces have greater capacity to effect articulatory changes and why. We need a concept of structure not as provisional but as relative permanenceopen for change but with relative stability (Chouliaraki and Fairclough, 1999: 125).

The point is not entirely justified: from the approach developed by Laclau and Mouffe one can very well account for relative permanence (one only needs to refuse an eternal one) as well as a relatively stable institutional reality (for post-structuralist discursive institutionalism: see for example, Moon, 2013; Panizza and Miorelli, 2013). Nevertheless, the problem is well understood: from the "thick" constructivism of DT, the central question becomes how to explain stability rather than change, similar to many other inquiries that tend to emphasize panta rhei by pointing out historicity or contingency (historians, symbolic interactionists, ethnomethodologists, post-structuralists, phenomenologists and so on). When meanings are constantly historicized -always considered as constructed, framed, genealogical, dislocated, always "postponed" in an always fluctuating arrangement of contingent elements-how to come to terms with the prolongation of order, discipline, institution and stability?

In this regard, Chouliaraki and Fairclough are certainly not the only ones, both within CDA and beyond, whom feel a need for a stable understanding of concepts, like "power" and "discourse" for example, not only as words in flux, but as somehow "out there", playing a crucially important role in determining how, why and by whom lives and politics are shaped-and therefore crucial to gain control over for creating a more equal world. As Hay exemplifies, many engaged socio-political researchers therefore assume an authoritative and intransitive space "beneath the surface" where notions like "power", "critique", "social inequality" or "discourse" can be grounded before changing the world through being critical: in their answer to the question of stability, those in the CDA community tend to agree that we are "subject to constraints that do not emanate from the discursive level but from structural relations of dependence, such as class, ethnicity, gender" and so on (Rear, 2013: 12-13). To arrive at positive change of the ruling order, they argue, we first of all need to get these invisible constraints right: we need to find out on the invisible relational structures prolonging order even under huge incentives for change posed by growing income inequality, racism, ecological shock.

Approaching the object with CDA. The approach of CDA practitioners to ecological questions, materiality, and biophysical object and things-clouds, particles, fabrics, aquifers, robots-can be construed along these lines as well: they are directly governed by this grand body of invisible structural relations, also known as the Laws of Nature. This is more than clear from Sjölander's notes on the CDA-DT roundtable discussions, on the subject of "extra-discursive reality".

The articulated views regarding the relationship between the discursive and the non-discursive to a great extent 
echoed the main disagreement between Laclau and Bhaskar when they met in a similar debate in Essex, England, back in 1998 [Laclau and Bhaskar, 1998]. The main aim of the meeting was to compare DT with critical realism, a philosophical perspective that has influenced CDA [...] one pivotal difference between them concerned the ontological understanding of the 'extra-discursive reality', or the non-discursive. First of all, they agreed that it existed. Bhaskar then stated that he believes in the possibility and actuality of a world without human beings, and therefore without discourse' [p. 11] [...] Laclau contested this perspective. Instead, he stressed that everything is constituted within discourse (Egan-Sjölander, 2011: 34-35)

From the Bhaskarian critical realist line of approach, then, the answer to climate sceptics can be a clear no: rising sea levels are ultimately not a question of interpretation. The complexities of discourse thrown upon researchers of social and political phenomena do not apply to natural scientists, as they focus on the "products of nature", which are, different than discourse, directly regulated by the body of invisible structures and mechanisms-a Newtonian-like whole of interconnected rules, the Laws of Nature. Within the critical realist ontology it goes without saying that we should listen to climatologists, physicists and biologists, because even if their discourse is not entirely immune to privilege, gender, status, and power, and even if knowledge and access to knowledge are thoroughly enmeshed with discursive political constructions, their objects of study are separate from discourse, directly governed by Natural Law.

Although, as mentioned, critical realism is only explicitly professed in CDA's Faircloughian current, all of CDA adheres to a range of a priori defined concepts like "power", "criticism", "discourse", and "ideology" in this way, and all of CDA clings in this regard to the cultural Marxism of Frankfurter critical theory (cf. Wodak and Meyer, 2009)-which explains why the Bhaskarian "depth ontology" is widely shared, even if not always explicitly articulated. Unsurprisingly, then, also the attitude towards materiality and the objective is similar, even in what is arguably the most inductive and historicist branch of CDA: the Discourse Historical Approach of Ruth Wodak. Consider Wodak's analysis of the notorious climate scepticism of former president of the Czech Republic, Václav Klaus, for example:

[Klaus's] claims are mostly justified by fallacies. The overall structure of Klaus's answers is dominated by two fallacies:

1. The fallacy of uncertainty assumes that science is uncertain in respect of the existence, causes, consequences and avoidance of climate change, environmentalist recommendations are not convincing and, thus, it does not make sense to follow these recommendations.

2. The second recurrent fallacy in Klaus's answers is the fallacy of nature: "since climate change is natural, ecological regulations concerning greenhouse gases are not reasonable, but irrational and wasteful".

Both fallacies can be discredited by a topos of numbers that refers to the vast majority of climatologists who agree that an anthropogenic climate change does exist with a very high degree of certainty. (...) In sum, we are able to conclude that Klaus's argumentation is highly fallacious and that there are plausible reasons to reject Klaus's neoliberal position and to accept a just limitation of human freedom for specific ecological reasons as concerning the well-being of the human species. (Wodak, 2009: 117)
Wodak's Discourse-Historical Approach, even if interestingly building on the radically relativist Alltagslogik [everyday logic] of rhetorical theorist Kienpointner (1992), clearly appears too prone to Habermasian-like ideal conversations, especially when we approach the object and biophysical science, and does not take rhetorical relativism, as substantiated by Kienpointner's extensive empirical studies, serious enough. Firstly, considering the communist legacy in the Czech Republic, Wodak is of course bound to lose the argument when she proposes to limit "human freedom" on the basis of rationality, rather than for example point out that with Klaus, freedom is only gained by a very small group of corporate entrepreneurs, but effectively diminished for everyone else. Relatedly while we should firmly stand with Wodak on pointing out both fallacies overall, in her analysis she misses out on accurately describing them. The first of Klaus' rhetorical fallacies, on uncertainty, has little to do with ignoring a "topos of numbers" and a "vast majority of climatologist", but pertains to Klaus's incorrect linkage between his correct observation "that science is uncertain in respect of the existence, causes, consequences and avoidance of climate change" and that "it does not make sense to follow these recommendations". Why should a degree of uncertainty not be allowed next to progressive policy based on a range of plain observations, such as the rise of temperature, seawater levels and carbon dioxide in the atmosphere, and their rather plausible interconnection by way of ingenious modelling? Wodak's "vast majority of climatologists" is an authority argument in disguise, overlapping with the tendencies in green discourse to rely on the invisible authority of Laws as above described. Her stance, moreover, enables Klaus to get away with his fallacy, as he can point to his correct depiction of science as reliant on uncertainty and emphasize the importance of freedom. Unsurprisingly, then, Wodak entirely refrains from expanding on the second fallacy on nature any further. Here it is first crucial to remark that Klaus does not deny climate change. Indeed, the problem is precisely that he frames global warming as "climate change", enabling him to again correctly state that such change is of all times. It then becomes clear what the fallacious character of his use of "nature" really consists of: Klaus presents it as simultaneously radically separate from human politics and an intransitive transcendental enforcer of what rational human politics should be about-in striking similarity to the CDA approach itself. With such a worldview, then, if nature is climate change, it follows that no action against such change can ever be taken.

The major problem for Klaus but even more so for CDA is precisely that in times of severe ecological crises nature cannot be held separate from human politics any longer, and can even less be relied upon for imagining and enforcing the timeless, intransient, "rational" structures on which both Klaus and CDA ground their entire enterprise. During state socialism and the early 1990s, Klaus was happily allying with those that pointed angrily to the destruction of Bohemian forests and the undisclosed but exceptionally high rates of lung-disease related deaths in the heavily air polluted north-west of Czechoslovakia-which helped to justify the "transition" from a Marxist-Leninist to a supposedly more rational neoliberal perspective. Many CDA-ers, on the other hand, currently enjoy pointing to rising sea levels, melting glaciers, rising temperature levels, severe loss of biodiversity, plagues of jellyfish in the Black Sea, the cyanide-spill in the Tisza, and so on, for rightly questioning the effectivity of liberal environmentalism, with its "environmental risk assessments" and "green growth". 9 But from both perspectives, it is difficult if not impossible to conceive animal, vegetative or non-living actors to disturb pre-conceived perspectives themselves. By CDA (and Klaus), clouds, nuclear particles, and aquifers are expected to provide stable grounding of one or the other "real" perspective, but not interfere with them, 
let alone rise up to them. Most CDA practitioners nowadays agree that there is "dialogue" between the "real" structural realm and the superficial world of discourse, but this far from changes the fundamentally held notion of two radically separate worlds, due to which materiality cannot be acknowledged as playing any active role.

There are other, related problems too, of a more direct political nature. Take, for example, the relations between actual obesity, capitalist power-relations, and nutrition discourses. According to CDA, with the right theory, corporate discourses on nutrition can be critically analysed, to reveal the corruption and irrationality of the neoliberalism that regulates it. Such assessments should reveal the fallacious premises of commercial nutrition discourses and educate the public, bringing them closer to rational conversation on the matter, thus influencing policymakers, which should then have the incentive to provide for progressive regulation. The international corporations of today, however, are time and time again perfectly anticipating "criticism" with an endless range of new strategic marketing innovations. Even McDonalds manages to brand itself as healthy and green nowadays. CDA practitioners might then again give a critical account, of course, but must again do so retrospectively -indeed $\mathrm{CDA}$ is essentially a retrospective enterprise (cf. Latour, 2004b). It will always be too late, always bitterly but literally "systematically" lagging behind events. Global warming, rising sea levels, honeybee mortality rate, plagues of jellyfish, or dying rivers may easily be given the same status as obesity in this regard. Indeed, under the Marxian spectre, CDA practitioners are likely to agree that global warming and obesity are similar metabolic problems that lay bare the bankruptcy of our current capitalist structures (the argument of Foster et al., 2011, returning to the Marxian notion of "metabolic rift"). Also here, corporate discourses can be "criticized" to reveal the corrupted or fallacious character of "neoliberal structures" behind it-but the threat that such critique is supposed to represent is without real danger, essentially because the activity of actual objects, actual physicality, the body, the coal that is burned, the honeybee, jellyfish, chemically polluted clouds, garments, nuclear particles in the Dnepr, perhaps the "means of production" to stay with Marx, are neglected, considered politically inactive, thus impossible to mobilize with or against.

\section{PART 2 resolves}

Thus, these are the shared problems in discourse analysis: according to the one school, of DT, all articulated accounts on objects are always already discursive. Although this is obviously correct, it often leads to a floating linguistic reductionism that overlooks the pro-active role of actual biophysical objects. The other school, of CDA, asserts an extra-discursive reality, as the realm of both material objects and relational structures, on the basis of which it criticizes discourses-but this separation between the discursive and the extra-discursive entails the immobilization of the latter. Under this separation, then, materiality and biophysical things can neither be considered as "active, affective, and politically significant" in their own right (Vaughan-Williams and Lundborg, 2015: 10).

Along these lines, both schools fundamentally critique empiricism, as Sjölander also remarks, although from two different lines of approach (2011: 34). CDA suggests one first has to figure out, without any empirical "trouble", the transcendental structures according to which the world is really working, so that these structures can be revealed through criticism of discourse, to achieve a more rational one. DT, on the other hand, warns more generally against the terror of empiricism in any narrow positivist setting, as this can only confirm what has been established to exist already, and bars us from thinking creatively.
DT therefore envisions our only chance for improvement of our condition lies in redefinition or invention of words and categories. Hence it recommends theoretical introspection.

Below a three-stepped solution is proposed that could help tie discourse analysis the actual Earth again, so to say, and in both cases, the above anti-empiricist stances present the most fundamental barrier to take physical, bodily, animal, mineral or atmospheric actors into account properly. Therefore, the first and perhaps most important measure: to embrace the "radical empiricism" of pragmatism and of William James in particular. Second: turning to the controversial Carl Schmitt for re-orienting our understanding of the political and, from there, to amend some of the ruling notions on politicization. Third: to take serious the findings of sociological science studies and material semiotics, notably the work of Bruno Latour, who has decidedly drawn physical objects and the objective into the orbit of a "thick" constructivism, only to then give up constructivism altogether under the argument that when it is applied to everything, it is impossible, even counterproductive to actively advocate it, because by doing so we already accept that it does not apply to everything. When this three-stepped trajectory has been followed, DTs circumvention and CDAs immobilization of material objects can be overcome, and we can move to the last section, in which this new sensibility toward objects is further consolidated by showing how it provides viable answers to the above other problems in discourse analysis over climatology and accounting for social stability as well.

Step 1: Adopting radical empiricism with William James. First and foremost, let us move to the work of William James. Many of our problems so far simply evaporate, become irrelevant, by learning on his view on empiricism: not narrowly positivistic but rather directed to break open "the laziness of intellectualist psychology"; that is, the laziness of both conformist status-quo positivisms and out of touch speculative idealisms, which he considered to be more closely allied than their practitioners themselves assume. James proposed to move to the actual stuff which makes up experience, whether in case of actual material objects like plants, fruits, minerals, animals, the honeybee, our own physicality, the mountain for the mountaineer, or for the geologist, quarks or atoms for physicist, but also in case of exclusively virtual things like intuitions, sadness and pleasure, religious experience, dreams, and so on. He went on to treat structured thought and its products from the same line of approach, including logical reasoning, language rules, profit calculations, theories, hypothetic mechanisms on how the world works, Laws of Nature, ideological perspectives, the metric system or the 24 -hour clock, or potentially climate modelling as well, or indeed any internally coherent systematics. These all flow from attempts to make sense of experiences, and become part of it in a re-fractured sense, but never fully overlap with it: experience is always local and always impossible to reduce to a globalized scheme. This is indeed a very "radical empiricism", as James (1996 [1909]: 280) calls it in A Pluralistic Universe, to distinguish it from "the doctrine of mental atoms which the name of empiricism so often suggests".

In short, for James and the pragmatism he co-founded, the field of empiricism must be enlarged substantially, to take "the real units of our immediately-felt life" (p. 287) as its always changing ground, and their intellectual systematization and measurement as necessary for proper functioning, but always inadequate.

The thickness, concreteness, and individuality of experience exists in the immediate and relatively unnamed stages of it, to the richness of which, and to the standing 
inadequacy of our conceptions to match it, Professor Bergson has so empathically called our attention (p. 280, italics added)

Interestingly, the claim to empiricism and the actual object can be re-appropriated in this way from the narrow status-quo positivism of the so-called "hard" currents in the socio-political sciences. As we all know, these are still forming its hegemonic core until today (or perhaps increasingly today, under the requirements of "Bologna"). Precisely radical empiricism, then, provides an open chance for those coming from discourse analysis or other "interpretive" currents, that find themselves (self-)ostracised on the "soft" outer layers, to blow up atomist reductionism and overtake its conformist practices from the inside, with the very claim to empiricism the latter falsely assumes to have monopolized. To do so, however, the anti-empiricist stance traditionally upheld in CDA and DT must be given up, as well as the fear for "hard" things. This is very possible especially from the DT position, as its emphasis on the constructedness of reality and its multiplicity, the important role of imagination and affect, its emphasis on political agonism, as well as difference, change, and contingency-and multitude-as having ontological primacy, resonate very well with James' proposals. As he says it himself: radical empiricism confirms multi-verse rather than uni-verse; it fully emphasizes multiplicity, or "manyness-in-oneness". 10

Here, then, inside the minimal pulses of experience, is realized that very inner complexity (...) You cannot separate the same from its other, except by abandoning the real altogether and taking to the conceptual system. (p. 284)

DT however must stop its Heideggerian resistance against the object and objectification per se: James certainly does not resist it, but rather embraces it. That systematization is always inadequate, does not mean that it is not absolutely required, certainly today, for proper orientation, enabling humans to communicate with each other and their surroundings. Indeed, where would they be headed nowadays without the metric system or climate modelling - not to speak of basic mathematics? James' approach, then, cannot be called anything but ontologically realist, but from the etymological sense of real as related to things, to sensed stuff-and not in the critical realist tradition of claiming an invisible, single and intransitive pre-structured "reality" that transcends or comes prior to decent empirical grip. As Henry S. Levinson points out in the foreword to James, "there simply is no real, but unexperiencable edition" (ix) - as especially the CDA community claims there is.

Step 2: Materializing the political, and politicizing the material, with Carl Schmitt. If things and objects are to be acknowledged as political agents, which is catastrophically inevitable nowadays, we have to look into what that actually means. After adopting a radical empiricism, we must move to the question of politics, the political, and politicization. Unexpectedly perhaps, when departing from the American pragmatist perspective, it is the dark-German work of Carl Schmitt-the contested "philosopher of national-socialism"-that is extremely informative in this regard.

Step 2b: Carl Schmitt as a materialist. During the current wave of rightwing nationalist-populisms, Schmitt's overall sharp-sighted observations demand to be seriously re-investigated, precisely because they were picked up and still are being picked up for legitimizing the most despicable regimes. In Der Begriff das Politischen (1963 [1932]) Schmitt observes that what goes by the name of "political" has to do with a non-rational dissociation between friend and enemy. As such, political differentiations emerge independently from intellectual dichotomies that regulate "social domains", which overlap strikingly well with James' systematizations. Schmitt calls them Zentralgebiete: religion (regulated by theology: belief/unbelief), morality (ethics: good/ bad), economy (economics: profitable/non-profitable), art (aesthetics: beautiful/ugly), technology (functional/non-functional) and so on (Schmitt, 1963: 1-10, 80-88). One might easily add: the scientific domain (true/false), the digital or Bayesian domain $(1 / 0)$, and so on.

But not only does Schmitt quite correctly observe that distinguishing between friends and enemies, the essence of the political, is something that takes place independently of such "domains" and its arbiters-which already makes him a thorough radical empirical materialist-he also notes that such distinctions run counter and can disrupt such arbitrage-which deepens his materialist stance. ${ }^{11}$ Schmitt accurately observes that a freely antagonistic political sphere demands either denial, breakdown, or unavailability of a "neutral" third party (unparteiischen Dritten) relying on one of the domains. The dichotomies that generate systematic models and regulate institutional reality, apparently, have a powerful capacity to order, neutralize, and pacify our otherwise uncoded and freely shifting experience Feindschaft and Freundschaft, and then to police the status quowhether through a religious or moral systematics (Catholicism, Protestantism, Islam), aesthetic logic (expressionism, realism, pointillism), or socio-economic models (Marxian, Keynesian, Hayekian). Therewith, arguably even more so than Machiavelli or Hobbes before him, Schmitt arrives at a "naked" conceptualisation of what das Politischen pertains to, directly rooted or even equated with the immediate experiential realm. Again, for this reason, he is quite compatible with the pragmatism of James.

Step 2b: Re-orienting politicization with William James and Carl Schmitt. Reading Schmitt helps a lot to break open the currently predominant notions of what politicization entails. The critical realist political scientist Colin Hay, cited already in the first part of this article, gives a good example of the established understanding. $\mathrm{He}$ describes it as the movement of a given topic from a non-political "realm of necessity" to the "governmental sphere" (Hay, 2007: 79-81, reproduced above in Fig. 1).

Hay's scheme is of great merit due to the concentric depicturing of what is at stake in politicization. However, when looking at the politicization from a Jamesian-Schmittian viewpoint, the scheme must be reversed (Fig. 2). It is common knowledge that the most unregulated, heated, real, violent debates generally take place in what Hay calls the "private sphere"-in bars, during dinners, or otherwise behind closed doors-where people talk more straight-out and uncoded about things. From there, some controversies reach a point of peacefulness and integration with what exists already, readying them for the more regulated, codified, pre-scripted, "rational" sphere of established businesses, churches, museums, academic conferences, government bureaucracy, parliament, or television. Here far less political antagonism is possible. Where there were any left, sharp edges are removed, and certain new notions, entities, or discourses gradually become gefundenes Fressen: controversies further depoliticize. If (a part of the) establishment leaves an opening, an issue may then finally enter the "governmental sphere". Indeed, if functioning well, the political establishment constantly attempts to identify new elements for further neutralizing, integrating, crystallizing, categorizing, and bureaucratizing them: depoliticizing them ever further. Only when it has not been looking out very well, or if there is a blockage somewhere, it may have to deal with 
"hot" subjects that suddenly burst into it directly from the multitude. In both cases, things are then slowly integrated into its codified crust-naturalized, pacified, structured, crystalized, normalized.

Beyond the establishment, following Schmitt's observations, truths may become so fully automatized and de-politicized that they end up in what Hay dubs the "realm of necessity". Clearly, then, a second amendment to Hay's scheme has to be made. Hay's "realm of necessity" is not radically separate from and opposite to, but, as Foucault has so well described, hanging over the "governmental sphere" like the atmosphere hangs over the Earth's crust, directly affected by it as well as regulating it. ${ }^{12}$ It is the realm where experience matters have given way to the hardto-break habits we live by and breathe every day, as unspoken common-sense systems, ethereal and ingrained in the unconsciousness, outside of speech. Lastly we may amend Hay by observing yet another sphere, where the "realm of necessity" has given way to a "view from nowhere": a hostile ultrasystematic vacuum where it was impossible to breath, at least without life support system, due to an absolute imposition of Laws-it is the favourite place of Reaganites and Stalinists for advocating journey's into space while claiming that "There Is No Alternative" (TINA), an orbit in which we are alternativlos, in Merkel's contemporary version.

Altogether, then, the process of politicization is grossly misunderstood if conceived simply as a movement from the "private sphere" through the "public sphere", to finally enter the "governmental sphere". Politicization is rather what happens when institutions-take for example the Convention of Geneva, or market rationality-break down, tumbling from the air of necessity, or even universal status, onto the governmental crust, and from there descend into the heated public and private layers. This generally happens under the disruptive force of new things, phenomena or experiences that cannot be easily integrated in the existing order: take the mass influx of migrants and refugees, for example, or "irrational" gambling with subprime mortgages. Politicization, or break-down of established order, thus happens in confrontation with some destabilizing other: a controversial new thing, actor, element, circumstance, group, and is necessarily risky or even dangerous. Besides the refugee crisis and the crisis over credit default swaps, the 2016 US election provides some good examples, in the personae of Trump and Sanders. Both argued to re-present actors and experiences excluded by the ruling establishment. Hence both could not be taken into account by the available theories, the "common-sense", of the established elites in the Democratic and Republican Party. A whole range of formerly inexplicit politesse within them-"politically correct" truthspoliticized, for the better or the worse, moving from the "realm of necessity", entering the public sphere. ${ }^{13}$

It should be noted that in such instances the said processes of de-politicization start simultaneously: the new or formerly excluded entities ignite deliberation over the way the community is gathered, which goals it sets for itself, how these are best achieved, and, finally, what should from then on be included, and what excluded from the community. Differentiation from Schmitt can now flow from the realization that we could, in a Jamesian geste, embrace this slow and often difficult process. In 1933 Schmitt joined those that disliked and opposed all existing procedures sui generis, favouring the breakdown rather than expansion of parliamentary order, leading to a return to the political in its most antagonistic, biophysical, violent form. A respect for politesse as such, for procedures of closure, of neutralisation of controversy, objectification, and gradual depoliticization is however very necessary for the persistence of any collective (cf. Latour, 2004a: 107-108, 140, 207; cf. Chateauraynaud, 2014; 2016: 3)-insufficient recognition of this was the deadly mistake of Schmitt, but also of Heidegger for example. ${ }^{14}$ That said, from a radical empiricist point of view, precisely for evading another eruption of radical violence, the existing establishment should better not exclude anything a priori to its neutralizing machinery. The stability and closure it generates are only stages in a circular process, the outcome of past processes of gathering, deliberation and composing. As every politician worthy of the name knows, the attempt to establish lasting peace is doomed from the start. Political order is a temporary theatrical exorcism of political antagonism as the ancient Athenians knew so very well, and something that constantly needs to be done anew. If the existing neutralizing procedures are closed to new actors, that is, when past closures or exclusions are maintained as a priori, as intransient and eternal, as universal rather than universalized, "the political returns" to speak with Mouffe, inevitably, but will then burst ever more violently into the establishment-simply because down below new forms are constantly shaping up, contingently moving and transforming anyhow (cf. Mouffe, 1993).

Step 3: Semiotizing the object, and objectifying semiotics, with Latour and STS. After taking up James and Schmitt, we are now well-prepared to take the final step and include biophysical things and objects in this processual view. This leads to what many call the "new objectivism" or "new materialism", and the domain of Bruno Latour, Isabelle Stengers, Jane Bennett, Donna Haraway, and the many others associated with one of the most exciting and enlightening new areas of study, that of science and technology studies (STS). In this field, with a radical empiricist attitude rather than theoretical seclusion, a range of discoveries has been made that, for discourse analysts, might at first be difficult to grasp, but then pleas strongly in favour of a radical constructivism, or rather post-constructivism. The key trick here is to extend semiotics to ecology, or vice versa, which has been the consequence of the work done in and around the Centre de Sociologie de l'Innovation, research centre at the Mines ParisTech engineering school, mostly significantly the early 1990s, by Bruno Latour, Antoine Hennion, John Law, Michel Callon and others (under the name of Actor-Network Theory, ANT). ${ }^{15}$ They relied on what Latour called "symmetric anthropology", that is, an anthropology not of pre-moderns by moderns, but precisely of those considering themselves to be modern scientists. This included ethnographical accounts on how moderns managed to establish their modernity by installing a strict dichotomy between pre-modern and modern, subject and object, and how they view and deal with things, (biophysical) objects and objectivity per consequence.

For this work to evolve the critique on structuralist linguistics and semiotics in the 1970s was of great importance, which forms a major point of overlap with DT. As is well known, this critique built on the observation that structuralist analysis had found out on the relationality and intertextuality when it came to signs, but the entire enterprise itself was ahistorical, and still depended on the premise that it should find out on processes of "meaning", the regulatory transcendental signifier within structuralist semiotics itself. What was, however, its "transcendental signified"? Both Latour and his colleagues in DT followed those whom concluded that there was no singular and stable "transcendental signified" at all, also not in the invisible or crossed out sense, as modern structuralist linguists silently assumed. Different from DT, however, for Latour and those developing material semiotics, this caused its animating power to crash from the heavens upon the Earth, so to say, to then explode and sink into everything, to become immanent in all things, while structuralist "intertextuality" was maintained, or in the blunt wording of Latour: "a semiotics of things is easy, one simply has to drop the meaning bit from semiotics" (Latour, 1996). 16 
From this approach, a biophysical whale, human institutions dealing with the whale and the word "whale", had never been radically separate from each other, the first real, objective and politically neutral and the other two subjective superficial and political. Rather they had always been "intertextually" connected, even if only in precarious and rather fluid networks. They had never been reducible to each other, of course, facing very different temporalities, in different orbits with very different strong connections closer by-yet they had always related to each other in an ecosystemic-social-intertextual way. After this insight, the modern distinction between disanimated "nature" and animated "culture" must be considered a thoroughly political act, using the stabilizing force of dichotomy along Schmittian lines to hide an underlying politicality from view, enabling modern communities of humans to colonize and exploit "products of nature" as they please-or to or use "nature" as a trashcan for unwanted leftovers produced by "culture". This enabled them to become the dominant geo- and biopolitical force today, but precisely with the near totality of that dominance, they became increasingly unable to ignore the hybrids they produced but transgress the modern dichotomies-from ocean acidification to robots to superbugs. Most importantly in the form of the severe ecological shocks, then, "the political returns". It is ever more evident every day that "subjective" political models, discourses and narratives with which humans talk about the whale, are related to the very objective survival of the species-and the other way around: it becomes ever more obvious that the shrinking population of whales affects the models, discourses and narratives used for conceiving the whale. With Stengers:

there is hardly an ecological situation on Earth where the values attributed by humans to different "products" of nature haven't already contributed to the construction of relationships among nonhuman living beings. The only singularity of political ecology is to explicitly assert, as a problem, the inseparable relation between values and the construction of a relationship within a world that can always already be deciphered in terms of values and relations. (Stengers, 2010: 31)

With this insight discourse analysts can finally come to terms with materiality and biophysical actors. The first thing to do, surely, is to apply concepts such as Mouffe's famous "chains of equivalence" across the domain of biophysical actors, political institutions, and language, construing collectivities of enemies and friends across these domains - indeed we must do so to evade the worst consequences of the ecosystemic-social-textual disasters aroused by the old interdictory dichotomies. While doing so the political sensibilities of discourse analysts may come in useful, moreover. Material semiotics and ANT have often been critiqued for their lack of self-conscious politicality, and undoubtedly they have shown a tendency to regress into fashionable but all too neutral descriptions of actor-networks. Renewed intercourse with discourse analysts may remind those enthralled by material semiotics where its loyalties in today's political landscape must lie. Indeed, does this approach not present us the most radical participatory equalitarianism imaginable?

We should perhaps take further caution then, and emphasize that the three-stepped shift, that we have now fully achieved, could well be called "objectivist", "materialist", "realist" or "empiricist", or even "behaviourist" or "positivist", but only in their proper etymological senses, and does certainly not switch back to a narrow empiricism or naïve realism, let alone a status quo confirming positivism or behaviourism. To their defence, Carnap, Hempel, Quine, Dhal, Skinner, and their inheritors in quasi-hard sociology and political science, also advocated against dividing science between the subjective humanities and objective physics-the former covering the socio-political realm of discourse, the latter covering lawful material neutrality. They assumed a Newtonian world, however, and assumed a single and invisible body of stable rules as governing the biophysical object, like critical realists. In retrospect, then, they were not empiricist enough: a priori of actual experience, they assumed a single Theory of Everything, which nowadays turns out to be problematic precisely within the domain of contemporary physics, by the incompatibility of quantum field theory and general relativity. Strikingly, positivist scientists like Stephen Hawking nowadays advocate the "end of physics" along these lines-that is, the utility but also the limits of scientific modelling, in striking resemblance to James (Hawking, 2002). On the basis of their empiricist faux pas, and contrary to James, the above advocated the study of humans with this misconceived "objectivity", so without taking serious bodily constraints, intuitions, or very real accounts on spiritual or religious experiences, paradoxically designing and prescribing systems and methods that stand out by detachment from experience and actual materiality. Today, under the failure of single Theory of Everything in physics, the premises of the ecological shock, and the critique on structuralist semiotics, their banner has become utterly problematic, or even ridiculous. Biological, physical and geological science that takes itself seriously today advocates attachment or attentiveness instead (or, in the wording of French pragmatism, prise or grip/grasp, cf. Chateauraynaud, 2014, n3). Along the way, with Latour and James (and indeed: Hawking), we open up for "experimental metaphysics" (for pragmatically orienting ourselves) in a way that the old narrow positivists (and critical realists) would find absolutely intolerable. Logical and causal modelling of relations remains crucial, but certainly not as the only possible or even most relevant -let alone that the experience of an "always already" should lead to the imagination of a single, stable and already unified whole of pre-existing relations. ${ }^{17}$

\section{PART 3 Answering old controversies}

We have at this point discussed a three-stepped procedure which, hopefully, helps the discourse analyst to increase her sensibility for materiality, and breaks ignorance over biophysical objects as political actors. In this third and final section, we shall see how this breakthrough can be further consolidated, by providing answers to the two other major challenges so far: on formulating a decent strategy toward climate scepticism, and on CDAs challenge to DT to take stability into account, even under huge incentives for change. Along the way, some questions on method will be discussed, and we then end this contribution by reviewing Marxian critiques on the Anthropocene.

Answering the problem of stability. With the above threestepped procedure CDAs problem with social stability vanishes. Chouliaraki and Fairclough may have had a fair point that there was not yet enough stability in Mouffe's "nodal points" to account for stability in the discursive realm, compared to their own transcendental a priori structures. To repeat the above quoted:

We need a concept of structure not as provisional but as relative permanence-open for change but with relative stability (Chouliaraki and Fairclough, 1999: 125)

Now that ecological crises leads to questioning the division between the human and bio-material world, in proper Anthropocenian fashion, it appears we can meet their requirement in the most elegant of ways: relative to humans, whales are far more predictable overall, and stones are rather stable indeed. Also stones 
however are nothing but very firm sedimentations, or material versions of Mouffe's "nodal points"-at least as long as we follow contemporary geological insight rather than pre-ordained biblical explanation: stones are born out of relatively unstructured magma and are once coming to an end. Their historicity is extended over billions of years-but this does not mean that they will not disintegrate and transfigure into something else, as is already recognized in geology since Hutton's Plutonism in the late eighteenth century, contra orthodox biblical hermeneutics. ${ }^{18}$ While the natural sciences thus acknowledged historicity of material objects long ago, ecological crisis now requires scholars of political discourse to do the same: man-made ecological shock robs objects and things of the eternality that they only seemed to possess relative to the human experience. This requires that material objects, like any other, become recognized as historical, temporary, relative, contingent, and all of this with humans and their discourse rather than apart from it-so that their appearance as stable relative to humans remains recognized as well.

The parenthesis that we can call the modern parenthesis during which we had, on the one hand, a world of objects, Gegenstand, out there, unconcerned by any sort of parliament, forum, agora, congress, court and, on the other, a whole set of forums, meeting places, town halls where people debated, has come to a close. What the etymology of the word thing-chose, cause, res, aita-had conserved for us mysteriously as a sort of fabulous and mythical past has now become, for all to see, our most ordinary present. Things are gathered again. (Latour, 2004b: 236, italics in original)

Such an appreciation of gathered objects, then, solves the riddle of stability.

It is always things-and I now mean this last word literally -which, in practice, lend their 'steely' quality to the hapless 'society'. So, in effect, what sociologists mean by the 'power of society' is not society itself-that would be magical indeed-but some sort of summary for all the entities already mobilized to render asymmetries longer lasting (Latour, 2005: 68).

Powerful people could until recently count on things for sustaining their "social order", as they could point out the relative conservatism of things to justify their own, literally objectifying the defence of one or the other eternal order. Indeed, positing an eternal intransitive order was what hitherto stable nonhuman systems seemed to emulate, and thus seemed acceptable to many people. More importantly, perhaps, the relative stability of material like paper, metal and wood enabled and still enables the preservation and transfer of the constructions, regulations, orderings, institutions and establishments invented and maintained by those in power. In the words of John Law:

social arrangements delegated into nonbodily physical form tend to hold their shape better than those that simply depend on face-to-face interaction (Law, 2009: 9)

Moses and Hammurabi literally carved them in stone, papyrus enabled St. Paul doing something lengthier, Justianus I then preferred the Codex, and contemporary hard-drives carry entire multi-national corporations, universities, and nation-states. The relative stability of objects even when displaced thus enables transitivity of James' (and Schmitt's, and Hawking's) the constructed neutralizing structures, roadmaps, linguistic rules, models of physicists, institutions, methods, terminological toolboxes, linguistic nodal points, theoretical perspectives, mathematical axioms, architectural plans, and measurement systems of all sorts-which would otherwise simply evaporate each generation. ${ }^{19}$

Think of how successful fictional characters have much longer lives than individual human beings even in oral traditions, and we get a sense of how drastically stabilizing uploading or inscribing them upon objects can be. This understanding, then, materialises the relative stability of Mouffe's nodal points, coming literally with an iron answer to the challenge laid out by the defenders of single-model transcendental structuralism in CDA, to provide for an explanation of stability from an ontological position of difference, relationality, relativism, and radical contingency-along the way reinforcing other attempts to finally do away with the old institutionalisms (Moon, 2013; Panizza and Miorelli, 2013). It explains, also, the appearance of linearity in technological change -which is not pre-given at all: technologies can and have been destroyed and forever forgotten. Indeed, it is only the loyalty of biophysical materiality relative to humans, or the elites among them, that has made it possible for them to be quite careless about reproducing their status quo, and to have no bother for what has been constructed already; stable material objects freed up part of the human brain-space needed for extending their "society" ever further (for example, Strum and Latour, 1987, on the difference between baboons and humans in this regard). To argue, on the observation of stability, for a priori acceptance of immobile transcendental structures, as Bhaskar, Gorski and critical realism either imply or explicitly propagate, now clearly becomes either anti-historicist regression, scholastic-intellectualist laziness, or outright authoritarian-altogether not that far from orthodox hermeneutical biblical traditions.

Answering questions on method. The question on method is one often returning one today, not least in the CDA community, as we have seen above. There is not much space left here to elaborate an entirely new method but luckily, then, this would also be beside the point: what the above three-stepped procedure suggests is not a new method, but rather (1) a loosening of the strict (vertical) boundary between the discursive-political and material-biophysical realm, which has made it impossible for methods, analytical roadmaps, models, and terminological toolboxes designed for the analysis and orientation of the former to be applied to the latter and vice versa; (2) a new (horizontal) boundary, disallowing methods, grids, analytical roadmaps or terminologies to disconnect from the controversies and areas they arose from by claiming single universal status, causing them to be applied unmodified and far too quickly on controversies and problems elsewhere. Crucial conceptual and terminological work is certainly ahead, but quite likely, most of the existing CDA approaches and DT toolboxes can be maintained under these premises-under possible enrichment by the work done in STS for example-if they are rendered "Earthbound" in this way. What might at times be severely disturbing however, especially where critical realist influence is felt, is that this entails constant adaption, re-invention, or re-orientation of methods and toolboxes. Any overly abstract doctrinal analytical grid would immediately run the danger of invoking the sort of intransitive primacy of the ideational sphere which, in times of ecological crisis, must be avoided at all costs. Let us accept Deleuze on (radical) empiricism in this regard:

Empiricism is by no means a reaction against concepts (...) On the contrary, it undertakes the most insane creation of concepts ever. Empiricism is a mysticism and a mathematicism of concepts, but precisely one which treats the 
concept as object of an encounter, as a here and now (Deleuze, 1994 [1968]: xx)

That said, we have to make sure that we do not fall in the opposite trap of regressing into postmodern "noncommittal language play" either, like DT sometimes tend to do, but again remain properly materialist, attentive, and Earthbound. The strong and mostly negative measures developed by Latour can be of great help in this regard (for example, 2005). To give an impression of what could then be caught and analysed, under this strange assemblage of James-Schmitt-Latour ${ }^{20}$ and discourse analysis (and otherwise after scale, circumstance and situation are grasped more carefully): take the politicization of clouds in Ruse in Bulgaria already mentioned. Or consider the Danube in Hungary in the 1980s: in the beginning of the decennium, a planned series of hydro-electric Danube waterworks between Gabčíkovo and Nagymaros were under full control of the government, as a prestigious project designed and administered by a class of politically neutral technical engineers employed by the Ministry of Public Works, overseen by the Central Committee of the MSZMP, the Hungarian communist party. Along the decade, the Marxist-Leninist models on catch-up modernization, which had been successfully installed after World War II, failed to provide proper orientation any longer and did hardly invigorate anybody, nor could centrally planned Marxist nation-state economics direct the real economy any longer. This produced an alienated younger generation unable to find satisfaction or project its ambition within the existing systems. They allied themselves to another set of actors: the Danubian ecosystems, equally alienated, externalized and ignored by the ruling system. A chain of equivalence came to be construed as the Danube Circle (Duna Kör), which included biologists, artists, humanist intellectuals, Danubian fish, eagles, aquifers, and the aesthetic qualities of the Danube Bend. While Marxist-Leninist ideal-real perspectives disintegrated ever further, "Nagymaros" became a matter of heated political debate. While the Danube was streaming outside of governmental control, thousands took the streets in 1988, in vocal alliance with the river. It provided the reformists in the MSZMP with the pretext to take control of the party and start Round Table negotiations, leading to regime change months thereafter, the very first in the region, as well as to the lasting abandonment of the Hungarian part of the plan.

Answering climate scepticism. From this angle, the answer to the question on climate scepticism must be a simple one: climate sceptics are quite right when they point out that the severity with which "Science with a capital S" is invoked by Ruth Wodak and others has a dubious political character. From a radical empiricist point of view, such Science is a hopelessly outdated "modernist myth", to speak with Latour once more. Sociological science studies have demonstrated convincingly how scientific practice thrives on perplexity over the world, which is generally described by scientists in rather vague or negative terms, while they also report over a fundamental anxiety they experience when invading it (Latour and Woolgar, 1979). Radically empirically: only recently a popular publication of Carlo Rovelli, one of the founders of loop quantum gravity, reported at length over the crucial role of insecurity about the ordering of the world as the very starting point of physics-interestingly he also stated that "in physics there is nothing that corresponds to the notion of the "now'", which once again confirms the Jamesian limited character of its systems relative to experience (Rovelli, 2015). In a previous book, on the pre-Socratic "first scientist" Anaximander of Miletus, Rovelli conceives the very core of scientific practice as the quest of exploring novel worldviews through "learned rebellion" against established perspectives (Rovelli, 2011). Obviously, also climatologists are constantly debating, arguing and disagreeing with each other. Even if, for understandable reasons, it is eagerly forgotten by hideous Newtonians like Ruth Wodak and many established greens, it leads no doubt that virtually all scientists consider the possibility of undermining established knowledge as the very cornerstone of their practice.

One of Latour's own major perplexities has been over the sudden transformation of this insecure but dynamic practice into secure "Science with a capital S" when the results of its endless learned debates are presented outside of the protective walls of universities and laboratories (Latour and Woolgar, 1979; Latour, 2005). In perfect Hegelian fashion, it seems, Latour describes how such "Science" behaves exactly as what scientific practice is effectively excluding. The Scientist as a shaman: by inscribing and engraving, a thing is turned into an object, but is then presented as a terrifying deterrent totem to end disagreement, to end debate and argument, because what has just happened appears as something mysteriously everlasting, eternal, universal. Along these lines Latour's conclusion, fourteen years later: We have never been modern $(1993)^{21}$. Climate sceptics, then, are simply correct when they point to such repressive mystifications of Science. Moreover, now that the actual scientific community, on the very basis of its observations, is increasingly compelled to advocate for shifts in policy, their political role becomes ever more visible. Perhaps surprisingly then, by far the best strategy for those on the side of practiced science is to denounce shamanistic "Science with a capital S", precisely in the name of practiced science itself: that is, to agree that scientific propositions are embedded in actual institutions, that scientists strike links with and between the Arctic, honeybees, aquifers, humans, and/or discourses, and this entails political engagement and political struggle, and is vocational in character. Radically impossible under "Science with a capital S", such a stance enables animated defence of practiced science-the perplexity it entails, the networking enmeshed in it, the hard work done by researchers in establishing and extending lucid referential chains between different things, new observations, already established truths, and past work; its reliance on instruments, financiers, governments, policy-makers and ideational perspectives, as well as the need for parliamentary control over the direction and budget for research; the necessary checks on such controls, to allow scientists to take new elements into account, and the debates concerning the balance between such values-and even for the need for policing established consensus, and politeness. Key is to emphasize that the machinery producing truth, objects and objectivity is not what makes them into falsehoods, but is precisely what produces truth (Latour and Woolgar, 1979). Abolishing "Science with a capital S" along these lines, then, makes it impossible to impose limits and borders without due process, as Latour would say it, or to fathom them as forever fixed. However, it enables to stress the importance of limits in preserving any collective or coherent body or thing-of the importance of what STS knows as "boundarywork". In other words, to admit that "limits to growth" are produced and require maintenance does not make such limits less crucial, but far more crucial. Similarly, precisely when "Science with a capital S" cannot be used anymore for enforcing restrictive systems without due process, under the threat of future catastrophe, it becomes quite evident that catastrophe is already upon us, and precisely due to the imposition of restrictive limits without due process (Swyngedouw, 2013, 2014). We can then start working frantically to construct, organize, build, extend, compose, and finally impose and maintain relations, objects, collectivities, structures, approaches, and limits. Under this strategy, then, climate sceptics will effectively lose their hitting stick, firstly because they lose the possibility of differentiating 
themselves from "Science with a capital S" and secondly because they can never match a similar passion, authenticity, and engagement with real things. As can now be pointed out, they are moving instead in networks that are firmly disconnected from actual reality, from any Earthbound materialist approach, checked by cloudy corporations rather than parliamentary democracy. Precisely similar to "Science with a capital S", they are cut off from common daily experience altogether, lost in a single-universal space, over the common good as best served by pursuing short term financial gain, for example. The problem is that when one denounces climate sceptics with "Science with a capital S", this legitimates both "Science with a capital S" and climate scepticism: the second as the rulers over subjects, the first over objects.

Answering criticisms of the Anthropocene. Jan Zalasiewicz and the Subcommittee of Quaternary Stratigraphy recently proposed to the International Commission on Stratigraphy to anchor the Anthropocene with reference to those particles left behind on the Earth's surface after nuclear explosions, providing a rather precise caesura for the current geological epoch: 17 h29 on 16 July 1945, when in New Mexico the first detonation of a nuclear weapon took place as part of the Manhattan project. Meanwhile, however, the notion has been critiqued; not without reason, critics point to the warm welcome the abolition of an autonomous Nature receives from eco-modernizers, with the notoriously ruthless Elon Musk as their frontman. According to Jason Moore and many others this is no coincidence: the notion "Anthropocene" rushes over divisions within the human species, and fails to signal that predominantly white, capitalist, imperialist males like Musk have been at the forefront of creating it: "Blaming all of humanity lets capitalism of the hook", according to Andreas Malm, writing for the acclaimed Jacobin Magazine (Malm, 2015). Indeed, as Bonneuil and Fressoz (2016: 70) remark, the Amazonian Yanomami Indians can hardly be considered co-responsible for global warming. The impression aroused by the Anthropocene is that "humans are all in it together", and thus gives an incorrect account of whom or what is actually responsible for the situation-hence a wave of current proposals in the last few years for replacing "Anthropocene" with "Capitolocene" (Moore, 2014), "Anthrobcene" (Parikka, 2014), "Anglocene" (Baviskar, 2015), "Eurocene" (Grove, 2016), "Oliganthropocene" (Swyngedouw, 2013), "Anthro-Obscene" (Swyngedouw, 2014)_or, best perhaps, the poetically anarchic "Misanthropocene" (Clover and Spahr, 2014).

In direct response to Malm, Latour has defended Anthropocene, as invented by those looking at the world from the viewpoint of material objects, animals or plants-that is, the geologists, biologists and physicists he studied-referring to himself as a "diplomat", responding that "coming from natural sciences, those who introduce Anthropocene are more attuned to the multiplicity of natural agents than to social agents" and that "the problem isn't the name, it's the excessive unity given" (Latour, 2015). There is sense in these remarks-as well as there is, then, a profound sense of irony in the offence taken by selfproclaimed Marxists after being confronted by a literally materialist or objectivist point of view. It is of great importance in this regard to recall how the practices that become questionable in the Anthropocene-that is, the division of nature and culture - can be traced to Plato. Malm's and Moore's remarks are certainly of importance, adding complexity, but showing that Plato is ultimately involved makes clear that the very conditions of contemporary capitalism are being broken with thinking the Anthropocene. Feminist and postcolonial studies provide notable insight here. Donna Haraway, the renowned biologist and feminist philosopher-whom recently added "Chthulucene" to the list (matching with Clover and Spahr as the author's favourite until now: Haraway, 2015)-pointed out in 1985 already that:

Chief among the troubling dualisms are self/other, mind/ body, culture/nature, male/female, civilized/primitive, reality/appearance, whole/part, agent/resource, maker/made, active/passive, right/wrong, truth/illusion, total/partial, God/man. (Haraway, 1991 [1985]: 177)

Isabelle Stengers and again Bruno Latour, among many others, have shown how Plato's dichotomy between "shadows" (or the culturally discursive "surface") and "Forms" (the intransitive structure associated with nature) provides perhaps the ultimate template for such divisionism, most famously in his famous parable on the cave, reproducing itself endlessly throughout history (cf. Haraway, 1991: 245n5, with reference to Jameson, 1984; Latour, 2005: 168-170; 2004a, b: 10-18; Stengers, 2010: 28-30; the parable itself: Plato, The Republic, Book 7). ${ }^{22}$ We might add to the list: man/animal, particular/universal, agency/structure, emperor/pope, the Moderns/Ancients, foundationalism/anti-foundationalism, philosophy/empiricism, science/ politics-and recall here the ordering and neutralizing effect of dichotomies pointed out with Schmitt in the second section. What we might surely add as well is what Marx observed as the tension between "use value" and "exchange value" of a commodity, or commodified object. Such variations legitimize a superior position of the Philosopher, which in modern times became the Scientist with a capital S, or the Critical Realist, or Venture Capitalist whom has broken away from his chains, and learned to endure the sunlight. He now "sees" abstract ideal-real Forms, and speaks about it to the prisoners, the normal people, but is completely incomprehensible to them, indeed often held in contempt by them, or even poisoned by them, like Socrates. Simultaneously however he is endlessly superior.

As mentioned: there is no problem with dichotomies in principle. Clearly, from a radical empiricist point of view, they may arouse heated intercourse, and provide for constructing new collectivities, or for enlarging chains of equivalence. They are also helpful in ordering and producing oversight. However, as has clearly been the case with the nature-culture distinction, a problem emerges when dualism is not considered a processual tool. As demonstrated above, afterward, new actors, elements or undetermined matters are hidden from view, and cannot enter the process of depoliticization, let alone government. Feminists like Haraway pointed to the idealized separation between man and woman in this regard-and pointed out that a structuralist inversion of positions was merely cosmetic, or possibly even worse. In the same vain, although often failing to remark that an inversion of positions could be worse, postcolonial theorists (Said, Spivak, Bhabha) pointed to the separation between "the West" and "the Orient". Indeed, from any proper empirical study of Western art and literature, especially of the nineteenth century, it is clear that "Man" is predominantly understood as relating to "woman" as the colonizer to the colonized. The first category, usually the self, or the observing narrator, is the colonizer, typically masculine, Western, modern, civilized, rational, abstract, in the know of the Laws of Nature. The second category, the other, is the colonized, the observed, feminine, Eastern, ancient, irrational, seductive, embodied, unpredictable, multi-interpretable: to be invaded and ruled over.

Interestingly, with Marx, it is quite clear that such divisionism started multiplying with the advent of capitalism, in Capital from the tension between biophysical use-value and abstract exchange value, leading to market exchange Value. Interest in the latter exploded after commercial elites ensured that this Value was supposedly much higher than their payment for an abstract 
"socially necessary labour time". The gigantic "surplus" thus generated led a capitalist mode of production to expand over the entire world by Marx's famous M-C-M" cycle-commodifying everything with the slightest use-value, or even imagined usevalue, causing the ecological "metabolic rift" already referred to above, at the end of the first section, to take on enormous proportions (Foster et al., 2011).

Meanwhile, however, from different angles, postcolonial and feminist authors have done everything they could to disrupt easy dichotomism, and with some success. In today's language the West still exists, just like "Man" as a universal category, but a multipolar world emerges in which the situation becomes ever more complicated. Can Marx labour theory of value not be problematized as well? A similar movement is already ongoing with regard to the Anthropocene and the division between nature and culture. Take any Western nineteenth century newspaper, compare it to one from today, and in a simplified sense, the observation is as follows:

"Man" (abstract) and "woman" (embodied) $\rightarrow$ "Man" (abstract but less and less in use), "humanity" (abstract but increasingly embodied), "a man", "a woman" and.... (embodied but increasingly abstract)

"The West" (abstract) and "The Orient" (embodied) $\rightarrow$ "The West" (abstract but increasingly embodied), "The East", "The global South" (increasingly abstract), "Amsterdam", "Chengdu", "China", "the Netherlands" (embodied but increasingly abstract).

\section{What is currently ongoing:}

"Nature" (abstract) and "culture" (embodied) $\rightarrow$ "Nature" (abstract), "this network" and "that ecosystem" (abstract and embodied), this plant, that human, myself, my laptop (embodied but increasingly abstract)

In our times of ecological crisis the disintegration of Platonic divisionism seems unavoidable indeed. What emerges is a pluriverse, to use the term that Stengers adopted from William James, in which the focus lies on experiential complexity instead. In it, the division and then marriage of two worlds remains a respected stabilizing procedure, useful for reproducing the status quo if need be. Also the working out of a coherent order, generated with dualisms, can be acknowledged. Crucially added to the equation however is the observation that division, marriage and visionary illusions of Unity and Value are always either preceded or followed by a complex multiplicity, and can always breakdown or move forward into to it: realities always also consists of other animated entities, whether of a physical, linguistic, ideational, non-living, human, or biological character, held together in precarious semiotic ecologies. Dichotomy, with Schmitt and James, systematizes and then de-politicizes them which, with James and Latour, must surely be considered a wonderful and necessary process, but can never lead to a single and stable systematics that fully monopolizes experienced reality. To remain with Marx, the questions pose themselves. Does the distinction between nature and culture, objective and subjective, not precede and enable the tension between exchange value and use value-and hence the abstraction of market Value? Did the mechanisms Marx described not above all assume a stable dichotomy between (exploitable) passive objects and (exploiting) active subjects? Does "surplus" only derive from imposing a stable disciplinary regime onto the human workforce? If state violence and appropriation of biophysical objects have something to do with it, what happens if, in the Anthropocene, biophysical objects themselves provide for a political point of view? If so, must dividing, measuring, and pricing the "labour-value" of past organisms, the sun, and present humans in the production of, for example, greenhouse gases not lead to madness? And what if the means of production turn out to be indistinguishable from the proletariat?

\section{Conclusion}

At this point, then, after referring to postcolonial theory, integrating East-West problematics, and a gesture toward Marx, we can safely return to where we started: in Eastern Europe. It is hardly surprising any longer that the meltdown in Chernobyl, the meltdown of the state socialist structuralism, the disintegration of the establishment overall, and the heyday of political ecology in the region all coincided. Unsurprisingly, moreover, the differentiation between "the West" and "the East" disintegrated simultaneously, until it was shortly abolished during the revolutionary period, between 1989 and 1991. The radioactive particles in the Dnepr, the poisonous industrial clouds thriving over Ruse, the threatened ecosystems of the Danube, the dying forests in Czechoslovakia all actively acted, chained with human outsiders, into the decay of Cold War dichotomy and modernist Marxist-Leninism, questioning the legitimacy of its doctrinal methods, theoretical Vision, static terminological toolbox, and proposed way of life. Doing away with narrowly linguistic discourse analysis and especially with Critical Realist schemes is absolutely required for grasping the interrelations here however. Afterwards, it is then even less surprising that Central and Eastern European politicians, in grave need for new perspectives (models, categories, theoretical schemes to orient themselves) quickly turned to the most promising, spirited and fashionable provider of such and so at the time: the neoliberal movement. Tellingly, the governments in the region were among the strongest advocates of the liberal environmentalist "framework", at the time considered rather progressive, when it achieved its global breakthrough during the Rio Earth Summit in 1992 (cf. note ix). In many countries it was written in law already before the Summit, by the anti-communist opposition of the 1980s that now came to be in charge (Vargha, 1992; Bernstein, 2002). New standardized responses to the environment were now available, and with them the new establishment was able to successfully pacify and neutralize ecological problems once again for the next two to three decades. Under the "return to the Europe" and "transition", followed by "Europeanization", ecological issues were dealt with as technical issues on effective policy implementation and "compliance with international standards"-fully codified, neutralized, and depoliticized. But surely, never forever.

\section{Notes}

1 There is currently a dispute ongoing between the object-oriented ontology (ooo) of Graham Harman and Jane Bennett's "vibrant matter" (cf. Harman, 2016; Bennett, 2012). This article tends toward Bennett in embracing a vibrant (or aleatory) materialism contra Harman, but sides with Harman in standing sceptical to Bennett's holism.

2 The term "Anthropocene" was coined by the Dutch atmospheric chemist and worldsystem theorist Paul Crutzen to denote the current geological epoch. First discussed in the 1980s, it made its breakthrough after an article in 2002 proposing the term in Nature (Crutzen, 2002).

3 That is, were it not for Althusser's vocal resistance to empiricism. For a great history of materialism from a discourse analytical perspective, from Marx to Latour: Beetz (2016).

4 "Real socialist" regimes and their centrally planned economies were without question ecologically destructive, even if the idea that they were much worse than "efficient" Western capitalism is to be disqualified as part of "Cold War Mythology”, as Zsuzsa Gille has convincingly shown (Gille, 2007). Also, to dismiss the problem as these regimes being "actually" state-capitalist would discard the problem far too easily-as insensible to the real and sincere intentions of those involved (Van Eeden, 2017). 
5 Empirical ontology, the quest for identifying, exploring and describing worldviews: "washing away assumptions about pre-given realities and instead asking questions about how realities are done in practices" (Law and Lien, 2012, p. 12). Blaikie's definition is of course only a shorthand to a complex question.

6 Clear proof of this are the combined CDA and DT discussion-panels organized at one of the leading discourse analytical annual meetings, the Interpretative Policy Analysis (IPA) International Conference.

7 Although his work has often had such an effect, Derrida was very far from saying that the whole of reality is reducible to language. Rather he emphasized how our experienced reality is understood in the same way as a words and texts are understood in structural linguistics: not as having a prefigured and self-evident meaning, or deriving their meaning from any prefigured setting (contra Chomsky), but situated, dependent on their surrounding, and changing their sense after being "read" a second time-or in the words of the Dutch Derrida-exegete Ger Groot, experienced reality, like a text, is as "a riddle that always only partially reveals its secrets". Cf. the foreword of Ger Groot to his translation of Derrida's Éperons. Les styles de Nietzsche (2006, p 12).

8 Varying on Dostoevsky here: "Even if someone proved to me that Christ is outside of truth and that in reality the truth was outside of Christ, then I would prefer to remain with Christ rather than with the truth."

9 The liberal environmentalist policy package, arising as the dominant "framework" for dealing with ecological questions after the Rio Earth Summit in 1992, rooted in the idea that a free market system can and should be congruent with its "environment". It consisted of "polluter pay principles", environmental tax measures, requirements for environmental impact research, "precautionary principles" in case of "environmental risk", and so on, as well as apposite slogans as "sustainable development", "green growth", and so on. (cf. Bernstein, 2002).

10 For post-structuralist or DT leaning analysts, it should perhaps be noted here that Derrida as well as Deleuze celebrated empiricism-although certainly not in any "narrow" manner. Derrida, on his attempt to deconstruct Rousseau's oeuvre by its supplements: "La sortie est est radicalement empiriste. (...) Mais ici le concept d'empirisme se détruit lui-même. (...) La pensée de cette opposition historique entre la philosophie et l'empirisme n'est pas simplement empirique et on ne peut la qualifier ainsi sans abus et méconnaissance.” (Derrida, 1967: 232, my emphasis). Deleuze, on the very first page of his Dialogues with Claire Parnet: "I have always felt that I am an empiricist, that is, a pluralist" (Deleuze and Parnet, 1987: vii). Also: Deleuze (1994 [1968], p. xx), quoted in paragraph 3.2 of this article.

11 According to Schmitt, because the friend/enemy distinction and the properly political essentially run counter to intellectual dichotomies, there is no rationale available that can legitimise the position of professional politicians, as there are in the Zentralgebiete: the business elite (profitable/non-profitable), cultural and artistic elites (beautiful/ugly), moral elites (good/bad), and so on. Politicians however still have to maintain themselves by successfully "neutralizing" the political tensions in the wider collective (Schmitt, 1963: 80-96). This means, in turn, that they tend tap the neutralizing power of the dichotomies in one or more of the Zentralgebiete. In our times, at least from the social-democratic left to the conservative right, the technoeconomical domain is by far the most popular for doing so: functional vs. nonfunctional and profitable vs. non-profitable

12 This of course is close to what Foucault in A History of Sexuality describes as emerging in the $19^{\text {th }}$ century: biological knowledge enabled new scientific objects like "population", "life" and "race" as intertwined with a desire for power and control, rendering biological life simultaneously into an object and political project. The wellknown shortcut here is "biopower". In view of the Anthropocene, Bonneuil and Fressoz describe the currently emerging "geopower" along these lines (Foucault, 1978:135 ff., quoted in Bonneuil and Fressoz, 2016: 88).

13 In this regard, the different French schools of pragmatist sociology, under the marker of sociologie des controverses, partly emerging in the slipstream of the work of Latour but certainly not limited to him, is highly informative. The works of Barthe (2005) or Chateauraynaud (for example, 2014, 2015, 2016), for example, are rich in examples and insightful schemes close to Fig. 2, not least in studies on environmental controversy.

14 Note that Chateauraynaud is careful to differentiate himself from Latour, among other things by maintaining (or re-introducing) a two-fold experience of reality, due to the different temporalities involved in objects, discourses and processes, leading to ambivalent judgments or ambiguous practices.

15 This is not the place to discuss the terminological repertoire of ANT in more detail. For those wanting to become acquainted with what has been written under the spectre of ANT so far, however: the Science Studies Centre of Lancaster University, the home base of John Law, has set up a great portal, conveniently giving entries to ANT literature by subject matter (Science Studies Centre, 2000).

16 As is well known, Derrida famously rebutted Saussure's system with his différance, which stands for many things, but prominently among them a degree of agency of the signs themselves in the semiotic process. After one takes the distinction between (the linguistic) signifier and what Derrida called Saussure's "transcendental signified" itself into the semiotic equation, a self-evident consequence must be drawn: this separation between the signifier and the signified, between word and matter, culture and nature, is already an intersubjective semiotic construction, deferred from matters.

17 Neither should the experience of the experience of an "always already" lead to a fluent but pre-unified "throbbing whole"; here Graham Harman, who argues against materialism, has a point indeed (2016, versus Bennett, 2012; cf. note i).
18 I am paraphrasing Latour here, quoting his Belgian colleague Isabelle Stengers, herself quoting Whitehead in turn, who reportedly said that "a stone takes a risk in continuing to exist" (Latour, 2012).

19 This resonates with the work of Bernard Stiegler, and especially McKenzie Wark, with regard to transitivity.

20 Although remarkable, perhaps, the assemblage "James-Schmitt-Latour" is not entirely idiosyncratic. As is well known, Mouffe is a careful reader of Schmitt, and Bruno Latour leans on William James quite explicitly, probably in the slipstream of Gilles Deleuze, who was a great admirer of James, calling him "un des plus grands philosophes américains". With Schmitt Latour is decidedly more careful, naturally, but he is unmistakably present in many of Latour's (2004a) writings; in Politics of Nature he hails Schmitt for "bringing back to light the essential [...] importance of the enemy whom one does not hate" for literally anything to acquire a political dimension (pp 146, 207-209, quotation 278n64). In the fifth of his (yet unpublished) Gifford Lectures (2013), Latour talks about Schmitt at length, mostly with regard to the requirement of absence of a "neutral third party" for things to become political.

21 Or more precisely, in We have never been modern: the modern constitution imposed a dualism between active subject (society, culture) and inactive object (nature, things), which however encouraged the creation of hybrid "quasi-objects", as it rendered the inscription of the virgin "object" by a penetrating "subject" a seductive thing to do. Now that these "quasi-objects" become so omnipresent, from the acidification of the ocean to the laptop, it becomes impossible to maintain the modern dualism. Hence the time has come to admit that we have never been modern

22 A row of chained prisoners-the "normal people"-sits with its back to the entrance of a cave. The prisoners are only able to see the cave wall. Behind them is a fire, and in between the prisoners and the fire people are walking behind a wall and carry objects or puppets of men and other living things. These represent Plato's ideal Forms, the shadows of which are the only known reality for the prisoners.

\section{References}

Agarin T and Grīvinš M (2016) Chasing the green buck? Environmental activism in post-communist Baltic States. Communist and Post-Communist Studies; 49 (3): 243-254.

Barthe Y (2005) Le pouvoir d'indécision: La mise en politique des déchets nucléaires. Economica: Paris, France.

Beetz J (2016) Materiality and Subject in Marxism, (Post-)Structuralism, and Material Semiotics. Palgrave Macmillan: London.

Bennett J (2009) Vibrant Matter: A Political Ecology of Things. Duke University Press: Durham, NC; London.

Bennett J (2012) Systems and things: A response to Graham Harman and Timothy Morton. New Literary History; 43 (2): 225-233.

Bernstein S (2002) Liberal environmentalism and global environmental govern ance. Global Environmental Politics; 2 (3): 1-16.

Bhaskar R (2008) A Realist Theory of Science. Routledge: London; New York.

Blaikie N (2007) Approaches to Social Enquiry: Advancing Knowledge, 2nd edition, Polity: Cambridge, UK.

Bonneuil C and Fressoz J-B (2016) The Shock of the Anthropocene: The Earth, History and Us. Verso: London; Brooklyn, NY.

Braun B and Whatmore S (eds) (2010) Political Matter: Technoscience, Democracy, and Public Life. University of Minnesota Press: Minneapolis, MN.

Baviskar A (2015) Chair's plenary: Anthropocene or Anglocene? Debating Cause and Consequence in the Great Climacteric. Annual Conference Royal Geographical Society - Institute of British Geographers (RGS-IBS), 3 September 2015, Exeter, UK.

Chateauraynaud F (2014) Postscript to the second edition: Being attentive to things. Pragmatic approaches to authenticity. In: Bessy C and Chateauraynaud F (eds). Experts et Faussaires. Pour une sociologie de la perception. Editions Pétra: Paris, France.

Chateauraynaud F (2015) Environmental Issues between Regulation and Conflict. Document de recherché du GSPR, EHESS: Paris, France.

Chateauraynaud F (2016) Towards a new matrix of risks: learning from multi-scale controversies. EEA Scientific Committee Seminar on Emerging Systemic Risks, 24 February 2016, Copenhagen, Denmark.

Chouliaraki L and Fairclough N (1999) Discourse in Late Modernity: Rethinking Critical Discourse Analysis, 1 edition, Edinburgh University Press: Edinburgh, UK.

Clover J and Spahr J (2014) \#Misanthropocene: Twenty-Four Theses. Commune Editions.

Coole D and Frost S (2010) New Materialisms: Ontology, Agency, and Politics. Duke University Press: Durham, NC; London.

Crutzen PJ (2002) Geology of mankind. Nature; 415 (6867): 23-23.

Deleuze G (1994) Difference and Repetition. Columbia University Press: New York. Deleuze G and Parnet C (1987) Dialogues. Althone Press: London.

Egan-Sjölander A (2011) Comparing critical discourse analysis and discourse theory. In: Gunnarsson-Payne J and Egan-Sjolander A (eds). Tracking Discourses: Politics, Identity and Social Change. Nordic Academic Press: Lund, pp 13-48.

Fairclough N (2003) Analysing Discourse: Textual Analysis for Social Research. Routledge: London; New York. 
Foster JB, York R and Clark B (2011) The Ecological Rift: Capitalism's War on the Earth. Monthly Review Press: New York.

Foucault M (1978) The History of Sexuality Volume I: An Introduction. Pantheon Books: New York.

Gille Z (2007) From the Cult of Waste to the Trash Heap of History: The Politics of Waste in Socialist and Postsocialist Hungary. Indiana University Press: Bloomington, IN.

Gorski PS (2013) What is critical realism? And why should you care? Contemporary Sociology: A Journal of Reviews; 42 (5): 658-670.

Greenpeace UK. (2016) Campaigning for The Laws of Nature in Southwark. Greenwire, https://greenwire.greenpeace.org/uk/en-gb/events/campaigninglaws-nature-southwark, accessed 18 February 2017.

Groot G (2006) Introductie. In: Derrida J (ed). Sporen. De stijlen van Nietzsche. Boom: Amsterdam, The Netherlands.

Grove J (2016) The New Nature. Boston Review, https://bostonreview.net/forum/ new-nature/jairus-grove-jairus-grove-response-jedediah-purdy, accessed 15 October 2016.

Hajer M (2005) Coalitions, practices, and meaning in environmental politics: From Acid rain to BSE. In: Torfing J and Howarth D (eds). Discourse Theory in European Politics. Identity, Policy and Governance. Palgrave Macmillan: Basingstoke, UK; New York, pp 297-315.

Haraway D (1991) Simians, Cyborgs, and Women: The Reinvention of Nature. Routledge: New York.

Haraway D (2015) Anthropocene, capitalocene, plantationocene, chthulucene: Making Kin. Environmental Humanities; 6 (1): 159-165.

Harman G (2016) Materialism is not the solution. The Nordic Journal of Aesthetics; 24 (47): 94-110.

Hawking S (2002) Gödel and the END OF PHYSics. Cambridge, UK.

Hay C (2002) Political Analysis: A Critical Introduction. Palgrave Macmillan: Basingstoke, UK; New York.

Hay C (2007) Why We Hate Politics. Polity: Cambridge, UK.

Howarth D (2005) Applying discourse theory: The method of articulation. In: Torfing J and Howarth D (eds). Discourse Theory in European Politics. Identity, Policy and Governance. Palgrave Macmillan: Basingstoke, UK; New York, pp 316-349.

Jacobsson K and Saxonberg S (eds) (2013) Beyond NGO-ization. The Mobilization Series on Social Movements, Protest, and Culture. Ashgate Publishing: London.

James W (1996) A pluralistic universe. University of Nebraska Press: Lincoln, NE; London.

Jameson F (1984) Postmodernism, or the cultural logic of late capitalism. New Left Review; I (146): 53-92.

Kienpointner M (1992) Alltagslogik: Struktur Und Funktion Von Argumentationsmustern. Frommann-Holzboog: Stuttgart-Bad Cannstatt, Germany.

Laclau E and Bhaskar R (1998) Discourse theory vs critical realism. Alethia; 1 (2): 9-14.

Latour B (1996) On actor-network theory: A few clarifications plus more than a few complications. Soziale welt; $369-381$.

Lang S (1997) The NGO-ization of feminism: Institutionalization and institution building within the German women's movement. In: Scott JW, Kaplan C and Keates D (eds). Transitions Environments Translations: Feminisms in International Politics. Routledge: London; New York, pp 101-120.

Latour B (1993) We Have Never been Modern. Harvard University Press: Cambridge, MA.

Latour B (2004a) Politics of Nature: How to Bring the Sciences into Democracy. Harvard University Press: Cambridge, MA.

Latour B (2004b) Why has critique run out of steam? From matters of fact to matters of concern. Critical Inquiry; 30 (2): 225-248.

Latour B (2005) Reassembling the Social: An Introduction to Actor-Network-Theory. Oxford University Press: Oxford.

Latour B (2012) Bruno Latour: The Modes of Existence project - YouTube. University of Cambridge, https://www.youtube.com/watch?v=gL3WBHT WDjI, accessed 18 June 2016.

Latour B (2013) Facing Gaia: A new enquiry into Natural Religion. Fifth lecture, War of the Worlds: Humans against Earthbound. Edinburgh, http://www.ed. ac.uk/humanities-soc-sci/news-events/lectures/gifford-lectures/archive/series2012-2013/bruno-latour, accessed 6 June 2016.

Latour B (2015) Capitalocene, anglocene, anthropocene. An Inquiry into the Modes of Existence (AIME) Project Website, http://www.modesofexistence.org, accessed 18 February 2017.

Latour B and Woolgar S (1979) Laboratory Life: The Construction of Scientific Facts. Princeton University Press: Princeton, NJ.

Law J and Lien ME (2012) Slippery: Field notes in empirical ontology. Social Studies of Science; 43 (3): 363-378.

Malm A (2015) The Anthropocene Myth. Jacobin, https://www.jacobinmag.com/ 2015/03/anthropocene-capitalism-climate-change, accessed 4 September 2016.

Meadows DH et al. (1972) The Limits to Growth; a Report for the Club of Rome's Project on the Predicament of Mankind. Universe Books: New York.
Moon DS (2013) 'Tissue on the bones': Towards the development of a poststructuralist institutionalism: Post-structuralist institutionalism. Politics; 33 (2) $112-123$.

Moore JW (2014) Capitolocene Part I: On the Nature \& Origins of Our Ecologica Crisis. Unpublished paper, Fernand Braudel Center, Binghamton University.

Mouffe C (1993) The Return of the Political. Verso: London; New York.

Mouzelis NP (1990) Post-Marxist Alternatives: The Construction of Social Orders. Macmillan: Basingstoke, UK.

Panizza F and Miorelli R (2013) Taking discourse seriously: Discursive institutionalism and post-structuralist discourse theory. Political Studies; 61 (2) 301-318.

Parikka J (2014) The Anthrobscene. University of Minnesota Press: Minneapolis, $\mathrm{MN}$.

Peirce CS (1934) The Collected Papers Vol. V: Pragmatism and Pramaticism. Weiss $\mathrm{P}$ and Hartshorne C (eds). textlog.de, http://www.textlog.de/7664-2.html accessed 22 August 2016.

Rear D (2013) Laclau and Mouffe's Discourse Theory and Fairclough's Critical Discourse Analysis: An Introduction and Comparison. Unpublished paper College of Economics, Nihon University, Tokyo.

Rovelli C (2011) The First Scientist: Anaximander and His Legacy. Westholme Publishing: Yardley, PA.

Rovelli C (2015) Seven Brief Lessons on Physics. Penguin UK: London.

Sayer A (2000) Realism and Social Science. Sage Publications: New Delhi, India.

Schmitt C (1963) Der Begriff des Politischen. Duncker \& Humblot: Berlin, Germany.

Science Studies Centre, Department of Sociology, Lancaster University. (2000) The Actor Network Resource: Thematic List of Publications, http://www.lancaster. ac.uk/fass/centres/css/ant/ant.htm, accessed 3 February 2017.

Stavrakakis Y (2000) On the emergence of Green ideology: The dislocation factor in Green politics. In: Howarth DR, Norval AJ and Stavrakakis Y (eds). Discourse Theory and Political Analysis: Identities, Hegemonies and Social Change. Manchester University Press: Manchester, UK; New York, pp $100-118$.

Stengers I (2010) Cosmopolitics I. University of Minnesota Press: Minneapolis, MN. Strum SS and Latour B (1987) Redefining the social link: From baboons to humans. Social Science Information; 26 (4): 783-802.

Swyngedouw E (2013) Trouble with Nature: Ecology as the New Opium for the Masses. Second meeting of the Human-Nature Platform: The natures of natures in political ecology, Lausanne, Switzerland, http://wp.unil.ch/societenature/files/ 2013/07/Swyngedouw-July2013.pdf.

Swyngedouw E (2014) Losing our Fear! Facing the Anthro-Obscene. ENTITLE blog - a collaborative writing project on Political Ecology, https://entitleblog.org/ 2014/10/20/losing-our-fear-facing-the-anthro-obscene. accessed 8 February 2017.

Tunmore S (2013) World's top climate scientists give us hope for a better future if we act now. Greenpeace International, http://www.greenpeace.org/interna tional/en/news/Blogs/makingwaves/IPCC-give-hope/blog/46795, accessed 8 February 2017.

Van Eeden P (2015) Chantal Mouffe houdt vurig pleidooi voor links populisme. $\operatorname{Vlam}(2): 13-15$

Van Eeden P (2017) Politicisation and depoliticisation of ecology: Polish and Romanian perspectives.

Vargha J (1992) Environmental perspectives in central and Eastern Europe. In: Verhoeve B and Bennett G (eds). Proceedings of a Congress of the Dutch National Council of Environmental Policy. Zwolle: The Netherlands.

Vaughan-Williams N and Lundborg T (2015) New materialisms, discourse analysis, and international relations : a radical intertextual approach. Review of International Studies; 41 (1): 3-25.

Wodak R (2009) The discourse-historical approach. In: Wodak R and Meyer M (eds). Methods of Critical Discourse Analysis. Sage Publications: London, pp 87-121.

Wodak R, Meyer M (2009) Critical discourse analysis: History, agenda, theory, and methodology, 2nd edition. In: Wodak R and Meyer M (eds). Methods of Critical Discourse Analysis. Sage Publications: London, pp 1-33.

\section{Data availability}

Data sharing is not applicable to this article.

\section{Acknowledgements}

The author would like to express his gratitude to the Fonds de la Recherche Scientifique FNRS, which has provided him with the financial support for this work. Thanks are also due to the CSI and Antoine Hennion for their hospitality. The author finally thanks Francis Chateauraynaud for reading and commenting on an earlier version of this piece, which has sharpened it significantly. 


\section{Additional information}

Competing interests: The author declares that there are no competing interests.

Reprints and permission information is available at http://www.palgrave-journals.com/ pal/authors/rights_and_permissions.html

How to cite this article: van Eeden P (2017) Materializing discourse analysis with James, Schmitt and Latour. Palgrave Communications. 3:17039 doi: 10.1057/palcomms.2017.39.

Publisher's note: Springer Nature remains neutral with regard to jurisdictional claims in published maps and institutional affiliations. (c) (i) This work is licensed under a Creative Commons Attribution 4.0 cc) International License. The images or other third party material in this article are included in the article's Creative Commons license, unless indicated otherwise in the credit line; if the material is not included under the Creative Commons license, users will need to obtain permission from the license holder to reproduce the material. To view a copy of this license, visit http://creativecommons.org/licenses/by/4.0/

(C) The Author(s) 2017 